\title{
Kønnenes kamp i sport og gymnastik
}

\author{
af Hans Bonde
}

»Naar Fredsvennerne faar Krigen afskaffet og Duelvæsenet er blevet kvalt i sin egen Latterlighed og Urimelighed, vil al med Blodsudgydelse forbunden Udfoldelse af Mandsmod tilhøre Historien. Men selve Mandsmodet og Styrken dør ikke for det. Den finder sit Afløb i Sporten. Og det utvivlsomt paa en smukkere og menneskeligere Maade end gennem blodige Bedrifter«.

Ovenstående citat stod at læse i det Billedblad-lignende skrift »Verdensspejlet « lige omkring århundredeskiftet. (1902/3, s. 429). Artiklens konkrete emne var idrætsugen i Kristiania (Oslo), men citatets budskab havde et mere generelt sigte: For det første hævdedes det, at det nyopdukkede fænomen sport bidrog til en videreførelse af den lange tradition for udfoldelse af mandighed i historien. For det andet blev det slået fast, at sporten ikke blot videreførte mandighedsdyrkelsen i en lige linje, men betød en svækkelse, en civilisering af »Mandsmodets« mere blodige former.

I det følgende vil spørgsmålet om idrættens betydning for århundredeskiftets mandighedsdyrkelse være et centralt tema; et tema som skal forsøge at kaste lys over følgende hovedspørgsmål:

1. Hvorfor blev gymnastikken frem for noget det 20. århundredes kvindelige kropskultur?

2. Hvorfor følte kvinderne behov for at skabe og dyrke en selvstændig form for kvindegymnastik?

3. Gymnastik og sport i dag. Har kønnene lært af hinandens kropslige udtryksformer?

Inden jeg går videre er det vigtigt at slå fast, at gymnastik og sport omkring århundredeskiftet var langt mere modsatte og forskelligartede kropskulturer, end de er i dag. Hvor sporten fundamentalt kan defineres som en kropskultur, hvor der gives en absolut, naturvidenskabelig målestok til vurdering af præstationen $(\mathrm{cm}$, gram, sekunder), forholdt det sig traditionelt anderledes med gymnastikken. Her var det overordentlig vanskeligt at give en fast målestok for præstationen, og de relativt få gymnastikgrene som fors $\emptyset$ gte sig med en »objektiv« vurdering af præstationens størrelse løb ind i store vanskeligheder. Dette belyses klart af følgende eksempel, som illustrerer den fundamentale forskel mellem sport og gymnastik:

I 1887 undlod bestyrelsen for Kjøbenhavns Gymnastikforening at uddele nogle medaljer som var blevet skænket klubben til præmiering af klubbens bedste gymnaster. 
Dette blev kritiseret i Tidsskrift for Sport, og kommunelæge Chr. Fenger fra klubbens bestyrelse svarede med at henvise til det vanskelige $i$ at finde vindere indenfor gymnastikken. Med ætsende klarhed slog han fast, at:

»Det gaar jo nemlig ikke med Gymnastik som med de fleste andre Sportsgrene, at der gives en absolut Maalestok for det præsterede Arbejde. Ved en Kaproning sejrer det Mandskab, der i den korteste Tid tilbagelægger den givne Strækning; det samme gjælder i Cyclesport, i Kapløb o.s.v.; det er Secondviseren paa Uhret, der med ubønhørlig Nøjagtighed afsiger Dommen. I Skydning giver paa samme Maade det højeste Pointantal den bedste Skytte, det gaar ligefrem efter Søren Mathisens Regnebog. Men med Gymnastik er det en anden Sag. Enhver ved, at det allerede ikke gaar an at sige, at den Mand som springer højest, springer bedst, men at det tillige kommer an paa, hvorledes hans hele holdning er under Løbet, under selve Springet og ved Nedspringet« (Tfs, 1887, s. 211ff).

Hvor gymnastikken altså tog sit udgangspunkt i en æstetisk og til tider sundhedsmæssig indfaldsvinkel, var sportens udgangspunkt et andet: At bevæge sig hurtigere eller højere, at løfte tungere vægte, at sparke flere mål ind, at indsætte flere knock-outer o.s.v., o.s.v.

\section{Sport som mandighedskult}

Den danske sportsbevægelse kan dateres tilbage til 1860 'ernes midte, men først i løbet af 1880'erne kan sporten siges at være blevet en massebevægelse med tusinder af aktive udøvere (Bonde, 1986, s. 68ff).

Hvem var så disse udøvere? Ja først og fremmest springer det i øjnene, at der langt overvejende var tale om en mandlig bybefolkning, i den allerførste tid med rødder i borgerskab og middelklasse, senere også i arbejderklassen. Kvinderne gjorde sig kun i mindre omfang gældende indenfor sporten, og da givetvis kun i form af kvinder fra de højere samfundslag. Hvis vi ser på, hvem som præsenterede, agiterede for og virkede for en udbredelse af sporten gennem formulering og udgivelse af litteratur om sport, gennem organisationsarbejde m.v., træder det samme billede frem: Sporten var en kropskultur skabt af og for mænd.

Ovenstående generaliserede billede af århundredeskiftets sportsbevægelse giver et billede af mændenes kvantitative dominans. Med udgangspunkt i en analyse af de bøger, tidsskrifter, digte og billeder som lancerede sporten i dens spæde startfase bekræftes det kvantitative billede med et kvalitativt: I denne sportslitteratur blev mandigheden og tilværelsens legemlige princip opfattet som gået tabt i historiens løb. Det store skræmmebillede var manden, som i takt med civilisationen og det stillesiddende og selvnydende liv ville degenerere til et lille, svagt, trangbrystet og skaldet individ (Ibid, s. 22ff).

Spørgsmålet er nu, hvordan sporten mere konkret mentes, at kunne bidrage til en genfødsel af det maskuline princip? For at give en fornemmelse af dette vil jeg opsplitte mandeidealet i tre dele; som bestående af en karakter, et kropsudtryk og en bevagelsesmåde. En sådan opdeling tjener selvfølgelig kun analytiske mål, og må derfor ikke opfattes som om manden (eller mennesket for den sags skyld) reelt er delt i en sådan dualisme, eller snarere trialisme. Modellen er derudover reduktionistisk, idet det som ikke ønskes tematiseret er barberet væk. 
I den tidlige danske idrætslitteratur var det vigtigste ideal for den maskuline psyke udviklingen af, hvad vi kan kalde en stålsat karakter, med vægt på følgende karaktertræk:

»Selvfornægtelse, Udholdenhed, Snarraadighed, Mod, Omløb i Hovedet og potenseret Viljekraft« (Lobedanz, 1895, s. 59).

For (sports)manden blev det anset for vitalt at kunne stålsætte sig selv imod alle former for sanselige fristelser, at kunne udvikle sin præstationsfærdighed og evne til at gøre karriere gennem selvbeherskelse i en tid hvor »Kampen for Tilværelsen« blev opfattet som stadig mere intens og indædt. (Bonde, 1986, s. 20ff).

Idrætslitteraturen rummede også en hyldest til en maskulin æastetik, altså til en skønhedsdyrkelse med manden som objekt. Dette gav sig udtryk på flere måder: Ikke kun i prosateksterne kan man finde eksempler på en dyrkelse af »den skønne mand «. Også i digtningen manifesterede denne tendens sig, f.eks. i Holger Drachmann's digt »Op Idrætsmand« fra omkring 1884 (Idræt, dec., 1884, Prøvenummer):
»Den krumme Ryg maa rettes - ja, og Musklens Væv maa flettes - ja,
og Sidde-Fedtet lettes - ja,
og Huden grundig tvættes - ja,...
Da bli'r vi selv et Glyptothek
af mandig skønne Former fuldt;...«

Drachmanns digt giver et meget pålideligt billede at det maskuline kropsideal i den tidlige danske idrætslitteratur. Populært sagt skulle den fedladne, ludende, slappe og ikke videre renlige unge danske (anti)mand gennem hærdende sportsøvelser omdánnes til en slank, rank, proper mand med muskler af stål. Idealet blev det gamle græske motto: »En sund sjæl i et sundt legeme«, eller mere præcist: En stålsat karakter i et hærdet legeme.

Dyrkelsen af den mandlige skønhed viste sig også ved Dansk Athletunions årligt tilbagevendende »Konkurrencer for smuk Legemsbygning «, som fandt sted fra 1902 1917. Tendensen ved disse konkurrencer gik klart i retning af en fremvisning af en hård, spændt muskulatur, store overkroppe og opspændte maver. Mange af de præmietagere som udtrykte netop dette kropsideal var faglærte arbejdere, som på denne måde kunne udtrykke en meget bastant og styrkepræget form for mandighed. Hermed er vi på vej til en dybere forståelse af den tredje komponent i mandeidealet, nemlig bevægelsesudtrykket.

Normerne for den maskuline bevægelsesadfærd viser ved et nærmere øjekast at være delt $i$ en styrke- og en hurtighedsbetonet form for bevægelse. Hvor arbejderne som nævnt i høj grad dyrkede den maskuline kraftudfoldelse, må borgerskabets mænd overvejende siges af have været fascineret af den hurtige mand. Dette viste sig f.eks. netop ved konkurrencerne for smuk legemsbygning, hvor dommerne i reglen var mænd med en borgerlig social profil. I reglen var de to læger og to billedhuggere. Disse dommere valgte f.eks. i 1903 og 1905 de mest lette og mindst muskulært stålsatte af præmietagerne til førstepladsen, henholdsvis det sportslige multitalent I.P. Müller og C.F. Goothardt fra fodsportsforeningen Freja. Både Müller og Gotthardt var fremfor alt 


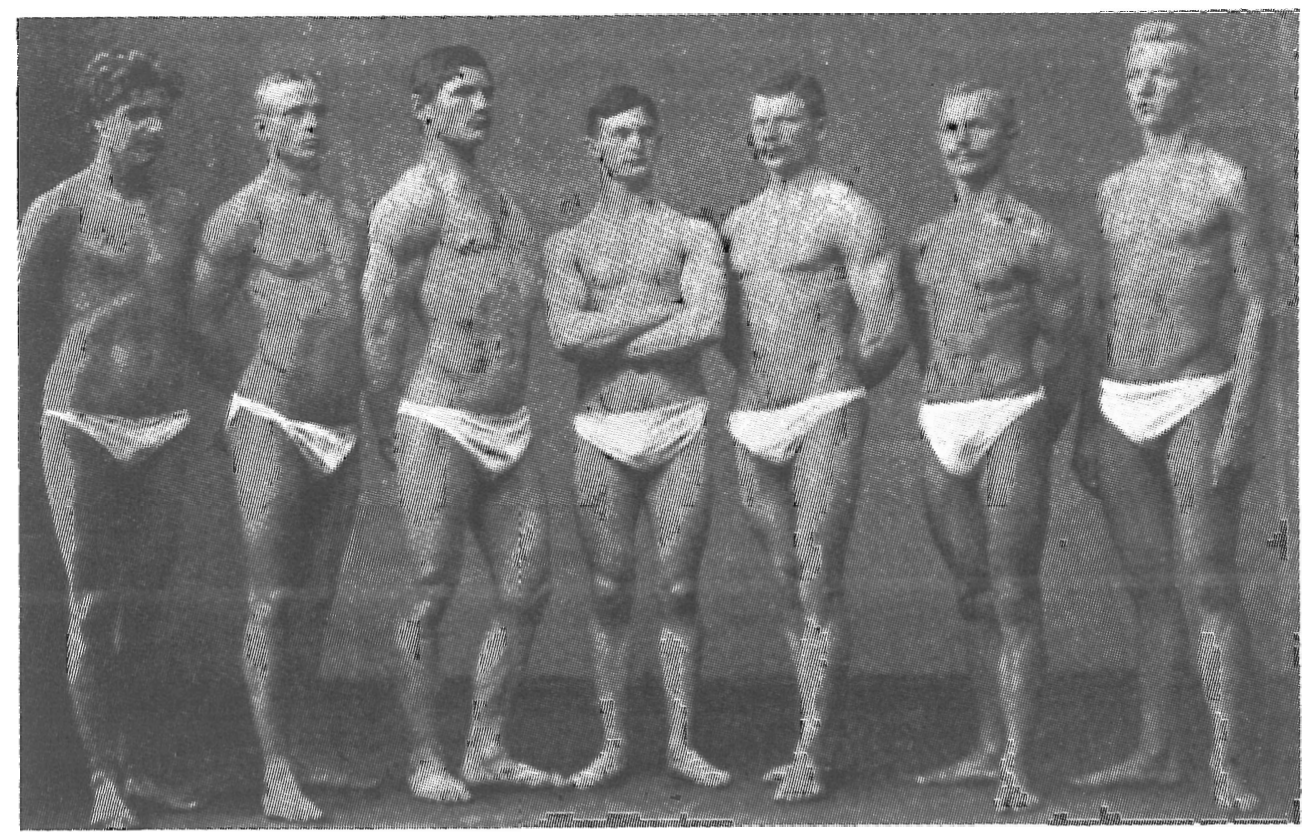

"De starke moend « fra Dansk Athlet-Unioms Konkurrence for smuk legemsbygning, 1905.

Kilde: Idratsbogen, bd. I, Gymnastik, s. 111.

dyrkere af hurtigheden i deres sportsudøvelse, og deres sociale baggrund var ikke arbejderklassens; de var henholdsvis løjtnant og model på akademiets elevskole.

Set fra et borgerligt standpunkt var problemet med arbejderatleternes - brydernes, boksernes og vægtløfternes - store, stærke kroppe, at de hæmmede hurtigheden. I.P. Müller f.eks. hånede de langsomme kraftsportfolk, der som han sagde:

»næsten ikke kan gaa for bare Kræfter«, (Müller, 1907 (1898), s. 154 og 1904, s.

18).

De sociologiske forskelle mellem borger- og arbejdermændenes sportsdyrkelse skal dog ikke overbetones. F.eks. dyrkede mænd fra begge klasser i vid udstrækning fodbold omkring århundredeskiftet. Tendensen var imidlertid klar, og mange borgerlige mænds fascination af det hastige bevægelsesmønster indenfor f.eks. kaproning og -sejlads og væddeløbsridning og -cykling viste sig også i digtningen, hvor de unge mænds fremdrift, målrettethed og fart blev hyldet. Sandsynligvis er det igen Drachmann der er på spil i det følgende citat fyldt med fart, tempo og humør:

»Maalet «

»At fare som en Pil over Vandet hen, det er flot, det er stolt og herligt min Ven!

Eller sæt dig til Hest for i rask Karriere at trodse hver hindrende Barriere.

Og følge den hvirvlende Cycles Fart, Det kan ogsaa gi'e Liv, men gjør det snart!« (Dansk Sportstidende nr. 3, s. 1, 1888). 
Alt i alt vil jeg karakterisere århundredeskiftets sportsmandsideal som en enhed af en stålsat karakter, et hærdet legeme og et hurtigt og/eller kraftbetonet bevægelsesmønster. Spørgsmålet bliver nu: Hvori kan enheden mellem disse idealer siges at ligge?

Et svar på dette spørgsmål kan i denne artikels sammenhæng kun blive helt summarisk, men skal alligevel antydes: Idrætslitteraturens karakterideal om selvbeherskelse som et middel til at stramme den unge sportsmand op til at gøre karriere blev i direkte kropslig forstand inkarneret i idealet om den spændte mandekrop og den hastige bevægelseskultur. Gennem at spænde i kroppen sker der nemlig en hæmning af alle sportsmandens tendentielt overjegstruende kropslige impulser. Hans lyst til en uhæmmet given sig hen til de »lavere «, dyriske drifter som at spise, drikke, elske, græde o.s.v. bliver i bogstaveligste forstand fikseret $i$ hans opstrammede muskulatur. Tilsyneladende helt uden at være styret af snoreværk fra højere autoriteter styres den hyperspændte unge sportsmand alligevel af et indre muskelsystem; han har i bogstaveligste forstand sig selv i stramme tøjler. Selvkontrollen er altså også en kropslig proces. (Se herom f.eks. Reich, 1942, s. 138, 145, 179 og 378).

Dette skal selvfølgelig ikke mistolkes i retning af, at alle sportsmænd omkring århundredeskiftet gik rundt med hårde spændte muskler, men kun forstås som en dominerende tendens i sportskulturens mandeideal.

For at få en idé om sammenhængen mellem karakter- og bevægelsesidealet kan det være hensigtsmæssig at se på begrebet karriere. Som nævnt mentes sporten i den tidlige danske idrætslitteratur at kunne udvikle den unge mands evne til at bane sig vej frem i verden og gøre karriere. Denne stræben efter at komme til tops antydes allerede i titlerne på de to citerede Drachmann-digte: »Op idrætsmænd « og »Maalet«, som kan forstås som en hyldest til maskulin opdrift og fremadrettethed. Begrebet karriere stammer oprindelig ikke fra arbejdets, men fra kropskulturens verden. Det betyder nemlig »en hests hurtigste bevægelsesform «, hvilket også fremgår af »Maalet «, hvor det siges »eller sæt dig til Hest for i rask Karriere...«.

Oprindelig - i adelsmandens eksercitier - var »karrieren « imidlertid kun én ud af mange forskellige bevægelsesformer: Den adelige eksercitieridning var nærmest en form for hesteballet, hvor hesten kunne bevæge sig i alle mulige retninger og tempi. Med den borgerlige hurtighedsridnings fremvækst skete der imidlertid en indskrænkning af hestens bevægelsesrepertoire, så karrieren - altså den hurtige, fremadrettede bevægelsesform - nu kom i højsædet og i kapridningen helt fortrængte det traditionelle, mangfoldige kropssprog. Den borgerlige løbebane og væddeløbshestens hvirvlende fart kan altså opfattes som havende en sproghistorisk sammenhæng manifesteret i begrebet karriere. Væddeløbshestens hastige fremfærd og idealet om den unge sportsmands fremdrift kan strukturelt siges at bygge på visse fælles mønstre.

Uden at ville argumentere for en deterministisk sammenhæng mellem arbejdets verden og sportskulturen, er der i det ovenstående antydet noget om mulige sammenhænge: Kroppens geometriske figurer på væddeløbsbanen kan siges at tegne omridset af en kultur, som bygger på en dyrkelse af fremskridtet og den rumlige og tidslige ekspansion.

I denne sammenhæng forekommer det oplagt at se idrætslitteraturens mandeidealer i sammenhæng med de revolutionerende krav, som stilledes til byernes mænd omkring århundredeskiftet. Tidsrummet 1870/80 - 1914 markerede jo ikke kun sportsbevægel- 


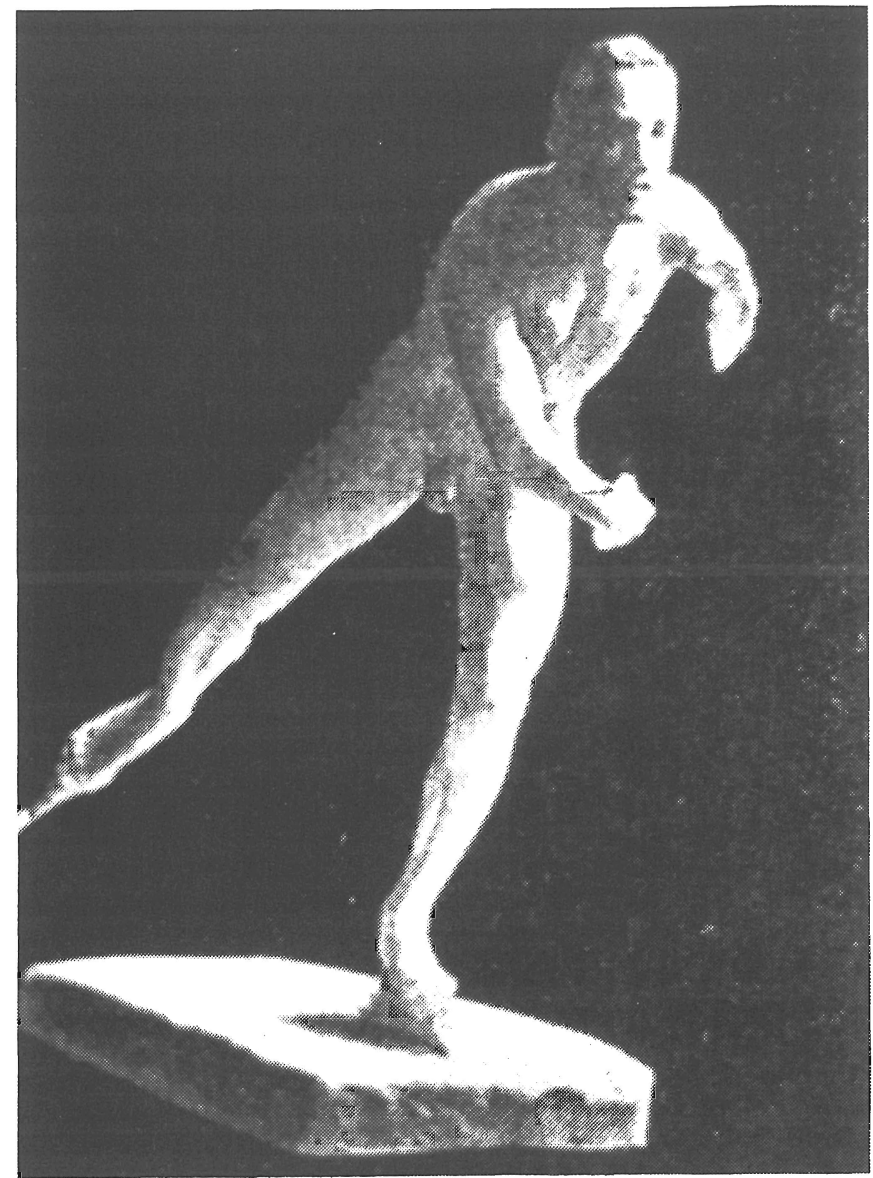

I borgerskabets sportsdyrkelse var den hurtige mand et ideal.

Statuen er ca. fra år 1900.

Kilde: Tidsskrift for Legems $\emptyset$ velser, Kbh., 1940.

sens, men også den industrielle kapitalismes gennembrud. Og som en del af denne samfundsforandring stilledes der nu langt større krav til mændene om selv at kæmpe sig frem i verden. Hvor adelens sønner kunne regne med at overtage deres fædres position, måtte det fremvoksende borgerskabs mænd $\mathrm{i}$ hver ny generation kæmpe hårdt for at gøre karriere, et projekt som ikke mindst $\mathrm{i}$ industrikapitalismens fødselsfase krævede jernhård selvdisciplin. I dette lys bliver idrætslitteraturens ideal om den unge mands hærdning af krop og sjæl og rastløst fremadfarende bevægelsesadfærd mere forståelig.

Også arbejdermændenes kraftbetonede form for mandighed kan ses i lyset af deres særlige stilling i den kapitalistiske produktionskultur. For dem gjaldt det jo ikke vitalt om at komme til tops i samfundet, i hvert fald ikke som enkeltindivider. Det var derimod vigtigt for deres arbejdsevne, i et samfund med så lav mekaniseringsgrad, at kunne bruge kræfter og f.eks. kunne løfte, trække og skubbe tunge redskaber og andre genstande. Dermed er det absolut ikke sagt, at arbejderne dyrkede kraftsport for at udvikle deres arbejdsevne. Det er blot blevet antydet, at forståelsen af arbejdsporten bør hente næring ved en konfrontation med arbejdermændenes hverdagskultur, og denne kultur var jo ikke mindst omkring århundredeskiftet fremfor alt en produktionskultur. 


\section{Angsten for amazonen}

De mandlige idrætsfolks og -skribenters forhold til sportsdyrkende kvinder var i udgangspunktet positivt. F.eks. blev det ofte betonet at idrætten kunne og burde medvirke til en frigørelse fra det kropsdeformerende korset (Ingeman Petersen, 1891, s. 45 og I.B, 1909, Fri Idræt, s. 3).

Forbeholdene viste sig først, når talen faldt på på hvilken måde kvinderne burde dyrke sport. Her viste der sig helt forskellige normer for den sømmelige bevægelsesadfærd og det passende kropsudtryk for kvinder og mænd. Frem for alt skulle kvinderne ifølge den tidlige danske sportslitteratur (1880-1914) normalt ikke bryde sig om at bevæge sig hurtigt. De var og forblev det langsomme, men også elegante og smukke køn. (For litteraturhenv. til hele det kommende afsn. se Bonde, 1986, s. 73ff).

Hvis vi for eksempel tager ridning, var det tydeligt, at kvinderne ikke skulle bryde sig om at spurte afsted over stok og sten. Ridning var i perioden udelukkende en aktivitet som blandt kvinder dyrkedes af »vore velhavende Klassers Damer«, og normerne for disse kvinders »præstationer « på hest var først og fremmest koncentreret om den korrekte, anstændige, sømmelige og pæne fremtoning. Der udkom i datiden en righoldig litteratur om, hvordan kvinder skulle opføre sig til hest, og det interessante er, at der konstant opereredes med, at en mandlig kavaler skulle påse, at kvinden optrådte værdigt og korrekt under ridningen. Der var tale om detaljerede adfærdskodekser, som fortalte, hvorledes den mandlige ledsager skulle påse kvindens dannelse udi ridningen, f.eks. opstigning på og nedstigning fra hesten. Kavaleren hjalp til ved denne proces og sikrede at den kunne ske på en sømmelig måde. Kvinderne skulle være meget bevidste om deres tøjvalg og f.eks. ikke lade håret flagre (usømmeligt) frit.

Det store debatemne i perioden var, hvorvidt ryttersken kunne tillade sig at sidde à la cavalier - med vilddyret direkte mellem benene - eller om de skulle forblive i sidesædet, med begge ben placeret i samme side. Denne ridemåde i damesaddel må siges at indeholde overordentlig store krav til kropskontrol og balanceevne, hvorfor det forekommer endnu mere grotesk med det undertrykkende galanteri, som vedholdende betonede den kvindelige svaghed. Henimod slutningen af perioden kan der dog i idrætslitteraturen registreres en tendens til, at kvinderne opfordredes til at ride à la cavalier. Og dette på trods af at »Modstanderne af Sædet à la cavalier gør gældende, at Ryttersken $\emptyset$ ver et ukvindeligt og mindre ladylike Indtryk paa Beskueren «. Kvinderidningen kan ses som en repræsentationsform for overklassens kvinder, en form som satte meget strikte rammer op for deres kropslige udtryksmuligheder. Frem for alt skulle de ikke bevæge sig for hurtigt. For at sikre dette kunne man vælge en hest, der skulle have:

»et godt og roligt Temperament, snarere lidt doven end livlig og dernæst have lette, elastiske Bevægelser... At se en Dame paa en Hest, der »bærer« højt i Trav eller har en tung stødende Gang, er aldrig noget smukt Syn, ligesom det heller ikke er godt for hendes Sundhed «. til:

Og hvis ikke kvinden selv kunne finde det sømmelige tempo, måtte kavaleren træde

»Ledsageren maa holde nøje paa, at Damen ikke forcerer Gangarten, en Fejl, som jeg tillader mig at bemærke, Damerne gerne gør sig skyldige $\mathrm{i} \ll$. 
Hensynet til kvindernes angivelige langsommelighed og svaghed blev også direkte taget op i forbindelse med valget og udformningen af sportsteknologi. I det foregående har jeg vist, at kvinderne ifølge idrætslitteraturen ikke skulle ride på en alt for hurtig hest. Dette gentog sig i valget af cykler. Ofte anbefaledes kvinder cykler med lige styr, mens mændene anbefaledes de hurtige cykler med nedadbøjede styr. Om tricyklen, som var en 3-hjulet cykel for voksne, blev det sagt, at den »navnlig egnede sig for Damer og ældre Personer «. Det siger sig selv, at en sådan cykel ikke kunne bevæge sig særligt hurtigt alene i kraft af dens vægt. Så når kvinder bevægede sig på sådanne monstrummer blev cykellitteraturens forestilling om kvindernes langsommelighed en selvopfyldende profeti. Også indenfor roningen anbefaledes kvinderne konstant lette både.

Spørgsmålet om hvem der skulle styre var prekært. Generelt kan det dog fastslås, at det $\mathrm{i}$ idrætslitteraturen altid var manden, som skulle styre, hvad enten det drejede sig om at styre en robåd eller en tandem.

Også i konkurrencereglerne blev der sat hindringer op for en kvindelig hurtighedsdyrkelse. Dette ses f.eks. indenfor roningen, hvor kvinderne helt frem til 1935 på trods af klare ønsker herom ikke som mændene blev bedømt på tid, men på stil (Korsgaard, 1982, s. 288ff, Jørgensen, 1986, s. 47-51 og Bonde 1986, s. 74f).

Frygten for at se kvinder optræde i den hårde »mandlige« konkurrencesport var ikke blot et spørgsmål om, at »Sportskvindernes« hurtige og kraftfulde bevægelser provokerede. Også angsten for, at den traditionelt mere sarte og spinkle kvindekrop skulle blive omdannet til et »maskulint « muskelpalads spillede ind. Ofte blev der i idrætslitteraturen advaret mod, at kvinden gennem sport ville blive mandhaftig, ja ligefrem udvikle sig til en amazone. F.eks. argumenteredes der i Illustreret Idrætsbog fra 1890 (s. 269) imod kvindelig kaproning ud fra den begrundelse, at:

»Det er vel ikke Meningen, at de unge Damer skulle uddannes til en Form for Sportskvinder eller moderne Amazoner, der mødte op ved Kaproninger og andre Væddekampe? «

Skræmmebilledet af amazonen kunne, som ovenfor vist, være den hurtige kvinde, men hun kunne også være den stærke kvinde, som dyrkede brydning, boksning, vægtløftning eller fodbold. Modstanden mod en kvindelig styrkeopvisning og muskeludvikling viste sig ved kvindernes praktisk talt totale fravær indenfor disse aktiviteter. Det har givetvis virket anstødeligt på de fleste af datidens mennesker af begge $\mathrm{k} \emptyset \mathrm{n}$, at kvinder udførte svedfrembringende og voldsomme bevægelser, løftede tunge ting, sloges fysisk med hinanden og sparkede hårdt ud efter en bold (eller et ben).

Endnu en form for begrænsning af kvindernes frie indtræden i sportsverdenen skal nævnes. Som sagt var der sandsynligvis i princippet hos de fleste mænd en venlig indstilling overfor kvinders sportsdyrkelse, blot det foregik ud fra en ikke kraft- og stykebetonet »kvindelig « æstetisk norm. Imidlertid viste der sig af og til en skarp barriere, når kvinderne fik den idé at indtræde i sportsklubbernes mandefællesskab. F.eks. udspandt der sig en hæftig diskussion i Dansk Fodsportsforenings regi i 1890'erne, efter at en kvinde havde luftet tanken om, at også kvinderne kunne have fornøjelse af at dyrke fodsport. Mændene frygtede, at kvinderne nu skulle deltage i deres aktiviteter. Kompromiset blev, at kvinderne dannede en selvstændig klub kaldet »Kvindelig Turistforening« for at understrege dens ikke-konkurrenceprægede karakter. 
Ikke alle kvinder accepterede de mandlige idrætsskribenters fors $\varnothing \mathrm{g}$ på at monopolisere hurtigheden. I løbet af 1890 'erne lykkedes det således de to cykelryttere, Johanne Jørgensen og Susanne Lindberg, at slå en lang række rekorder, sat af mænd vel at mærke! Dette vakte international opmærksomhed. At Johanne Jørgensen næppe kunne siges at tilhøre et specielt langsomt køn fremgik af hendes resultater. I en jubilæumsbog om »Dansk Bicycle Clubs Historie« lød det f.eks. om Johanne Jørgensen:

»Med ufattelig Energi gik hun ud efter den ene Rekord efter den anden og slog næsten alt, hvad hun kom i Berøring med... Hun trænede energisk og satte sig som Maal at slaa de Rekorder, Mændene satte. Paa 12 Timer kørte hun 33,5 Mil, og slog dermed Ingemann Petersens Rekord med 2,5 Mil, til trods for at hun kørte i Storm og Regn og på opblødte Veje«.

Johanne Jørgensen var i øvrigt også den første Københavnerinde, som vovede sig op på den nye fartmaskine: Safetycyklen. Og i 1897 blev Susanne Lindberg verdensberømt ved at køre $1000 \mathrm{~km}$ på 54 timer og 18 minutter. Hvor mange mænd kan klare det? Af mere kuriøs karakter er det forhold, at Johanne Jørgensen slog cykelrytteren Ingemann Petersens rekorder. Kort forinden havde han nemlig i bogen Cycle-Sport slået den kvindelige langsommelighed fast.

Sådanne symbolske sejre for kvindekønnet var uhyre vigtige, fordi de brød med myten om, at kvinder ikke kunne og burde dyrke hastighedssport. Problemet var dog, at det konstant var mændene, som definerede grundlaget for kampen. Målet blev at vise, at en kvinde var lige så god som eller bedre end en mand til at honorere krav, som traditionelt blev forbundet med begrebet mandighed.

I begyndelsen af vort århundrede skete der imidlertid et nybrud i forhold til denne kamp på mændenes præmisser, ikke mindst i forbindelse med den finske gymnast Elli Bjørksteins optræden ved olympiaden i Stockholm i 1912. Herefter fik kvinderne for alvor afgørende indflydelse på deres egen kropskultur. Til forskel fra sportens hårde, hurtige, eksplosive og fremadrettede bevægelsesmønstre, blev vægten lagt på afspændte, rytmiske, totale og flydende bevægelser.

Konkluderende må den massive kvalitative og kvantitative maskuline dominans $\mathrm{i}$ sportsverdenen have medvirket til, at århundredeskiftets kvinder i højere grad end nogen sportsgren tog gymnastikken til sig. Gymnastikken byggede jo på en æstetisk og sundhedsmæssig indfaldsvinkel, hvilket var i langt bedre pagt med det herskende romantiske kvindeideal (Annerstedt, 1983, s. 22) end sportens præstationskultur. Hermed er vi på vej ind i gymnastikhistorien.

\section{Den svenske gymnastik}

»Da vorder Mænd med Magt og Mod

og Tugt og Virketrang,

hvem Goterstammens Vikingblod

end bruser gjennem Haand og Fod;

til ædel Daad paa Nordens Vang

de vokse op en Gang«.

(Vilhelm Olsen) 
Til forskel fra sporten som fortrinsvis dyrkedes af byboerne, domineredes bøndernes kropskultur omkring århundredeskiftet af gymnastik, den såkaldt svenske gymnastik. Til forskel fra byernes sport var en stor del af de »svenske « gymnaster kvinder, og dette kunne give anledning til en opfattelse af gymnastikken som kønsneutral eller direkte som et fælles udtryk for de to køns kropslige idealer og væren. Som det vil fremgå af det følgende, opfatter jeg en sådan synsmåde som i vid udstrækning romantiserende.

I det følgende vil jeg plædere for, at også den svenske gymnastik havde et stærk præg i retning af mandighedsdyrkelse, hvilket allerede antydes i det indledende vers, som f.eks. kunne blive sunget ved de »svenske « gymnasters ind- eller udmarch efter en gymnastiktime på højskole. Sådanne sange virkede i retning af at fastholde den ideologiske målsætning bag den svenske gymnastik (Daneved, 1978, s. 1f og 99).

\section{Kroppens sprog som historisk kilde}

For at undersøge elementer af mandekultur i den svenske gymnastik er det en mulighed at se på, hvad de historisk aktører (elever og lærere m.v.) faktisk har sagt, om deres gymnastik. Skønt en sådan fremgangsmåde givetvis giver vigtige informationer, vil den ikke stå i centrum i det følgende. Tværtimod er ideen især at fokusere på hvad gymnasterne har gjort, altså den faktiske måde at stå på, bevæge sig på, kropsholdninger, musklernes spændingsniveau o.s.v. En sådan fremgangsmåde vil kunne indfange normer og holdninger, som er for selvfølgelige eller ubevidste til at optræde i de manifeste ideologiske vidnesbyrd, eller som direkte søges bortforklaret af de historiske aktører.

En sådan kropshistorisk indfaldsvinkel er jo allerede blevet fors øgt i forbindelse med denne artikels sportsafsnit, men der skal nu forsøges en præcisering af analysemetoden. Ved analysen af kropsidealet i sportskulturen udgjorde de mandlige skønhedskonkurrencer en central kilde. Et lignende materiale findes ikke for gymnastiḱkens vedkommende. Dette betyder imidlertid ikke, at vi er afskåret fra at undersøge kropslige idealer og udtryksformer indenfor den svenske gymnastik, for gymnastikken kan fundamentalt beskrives som én stor skønhedsbestræbelse. Til forskel fra sportens mere vilkårlige og situationsbestemte bevægelsesmønstre, fandt der i gymnastikken en direkte og bevidst kropsformning sted. Kildematerialet $\mathrm{i}$ form af billeder og billedtekst, hvad angår de ønskede kropsholdninger m.v., er derfor nærmest overdådigt.

Den metode, der i det følgende anvendes, kan betegnes som en form for kroppens semiotik, altså en metode der betragter kropslige udtryksformer som en form for tegn eller sprog, som kan tydes og omsættes til dagligdagssproget (dog ikke uden tab af betydninger). Metoden kan også populært beskrives som en form for historie indefra. Det vil sige, udgangspunktet er kroppen selv; f.eks. rygradens, musklernes og åndedrættets formning i den historiske proces. Det historiske fokus starter altså hverken »oppefra« (fra de herskende klasser og den politiske historie og idéhistorien), ej heller »nedefra « (fra arbejdernes og den materielle og hverdagslige væren), men »indefra «, fra sanserne, bevægelserne m.v. Ud fra dette begyndelsespunkt kan der så etableres-forbindelseslinjer til andre af tilværelsens aspekter; køns- og klassestrukturer, religion, politik, musik, økonomi o.s.v.

I det følgende vil jeg dog hovedsagelig indskrænke mig til at inddrage bondegymnastikkens økonomiske og til dels politiske aspekter. Det giver sig selv, at en sådan metode må være tværfaglig, allerede p.g.a. de antydede semiotiske og naturvidenskabe- 
lige (åndedrættets funktion m.v.) indfaldsvinkler. Dertil kommer et stærkt psykologisk element i tydningsarbejdet. For mit vedkommende er inspirationen primært hentet fra Wilhelm Reich og Norbert Elias.

Netop idrætshistorien har oplagte muligheder for at bibringe den traditionelt skriftog verbalorienterede historieforskning nye impulser. For fundamentalt handler idrætten om sansning, kropslighed og fascination, hvilket giver sig udtryk i et uhyre stort billedmateriale, der lidt flot formuleret kan forstås som et udstillingsvindue for kroppens sprog.

\section{Gymnastikkens semiotik}

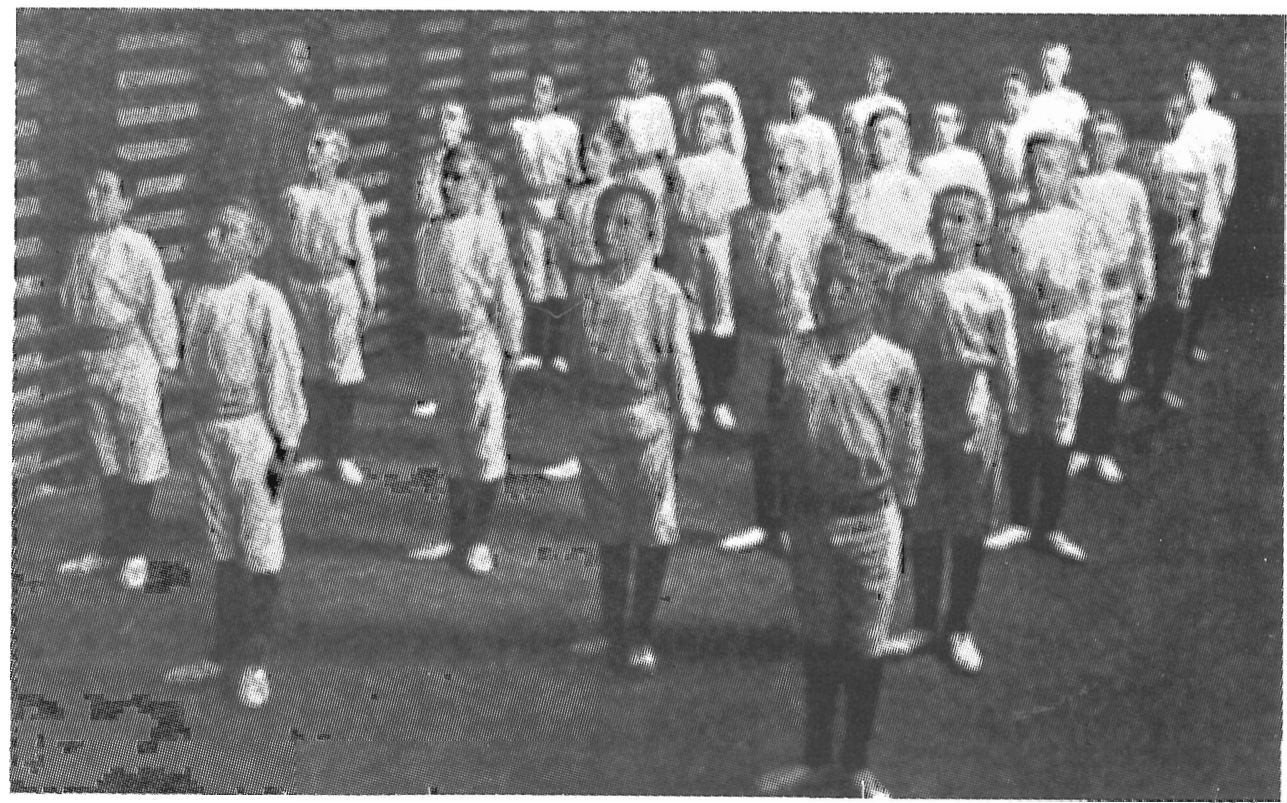

»Brystet ud og maven ind! «Skoledrenge i retstilling på den første skole, der indførte svensk gymnastik i Danmark, Gregersens Realskole. Bemark lareren: K.A. Knudsen!

Kilde: Idratsbogen, op. cit., s. 20.

Retstillingen: Denne stillings betydning for den svenske gymnastik kan ikke overbetones. I alle værker som bygger på den traditionelle svenske gymnastik er det form- og indholdsmæssige udgangspunkt for de fleste andre $\emptyset$ velser, retstillingen. (Theilmann, 1908, s. 19f, Knudsen, 1916 (30) s. 101ff, Reiter, 1908, s. 8f, Thörngren, 1912 (05), s. 74f, Thulin, 1921, s. 2).

En typisk definition på retstillingen kunne lyde således (Theilmann, 1908, s. 19f):

»Hælene samlet og lige langt fremme; Fødderne drejet lige langt udad til en Vinkel paa $90^{\circ}$; Knæene strakt; Overkroppen holdt lodret lige over Benene; Ryggen ret. Naar Rygradens Krumninger rettes ud saa meget som muligt, udvides og løftes Brystkassen samtidig, saa at Brystet er længere fremme end Underlivet. Hovedet godt løftet med indtrukket Hage. Naar Hagen trækkes ind, og Nakken løftes, rettes ikke alene Halshvirvelsøjlen ud, men ogsaa den Del af 


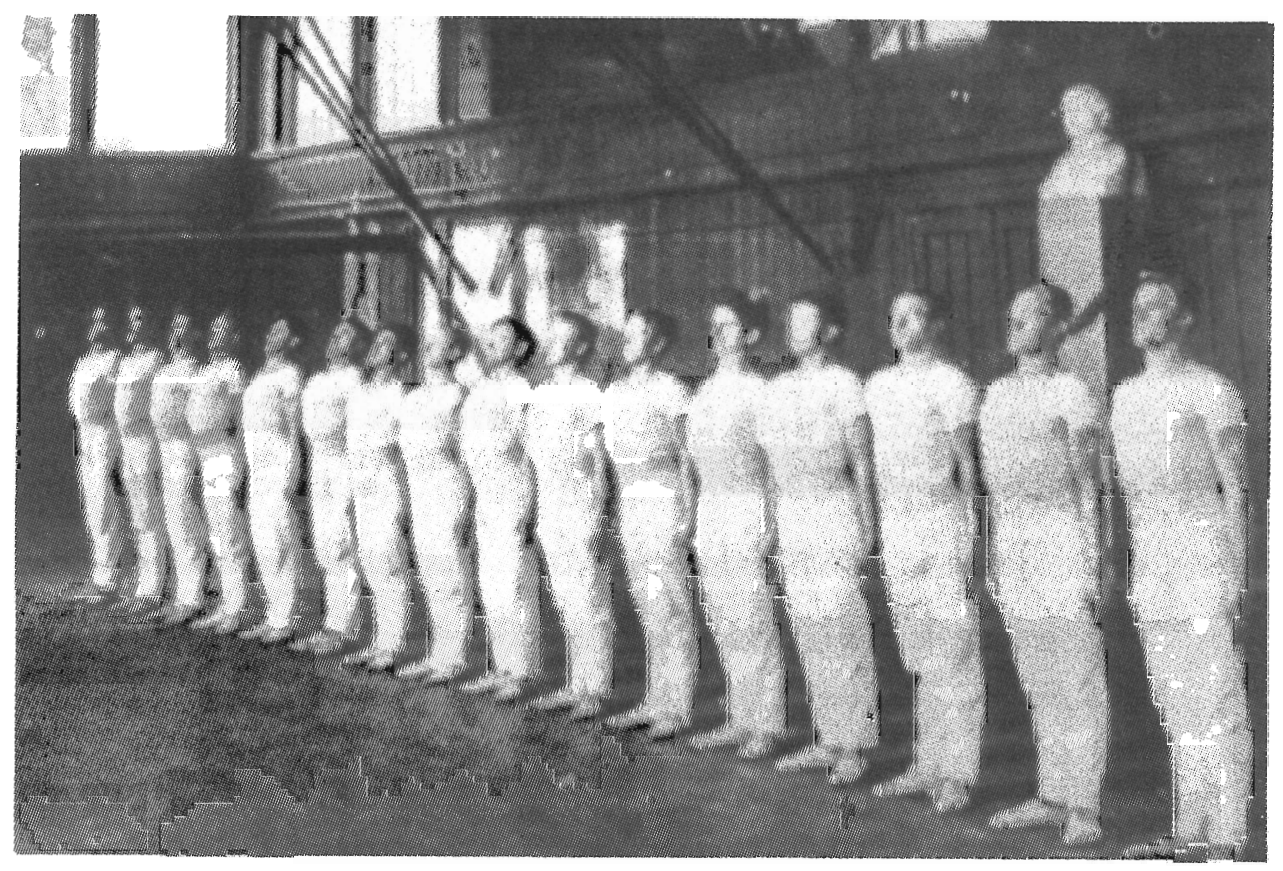

Svenske gymnaster i Vallekilde Øvelseshus 1915. Bemark de bagestes ekstreme bagudbøjning. Busten i baggrunden bryder ikke de stive stramme kroppes rytme.

Kilde: Korsgaard, 1982, s. 105.

Hvirvelsøjlen, der ligger nedenunder. Naar Bugmusklerne trækkes sammen, hindres en for stærk Svejning af Lænden. Skuldrene tilbagetrukket og sænket. Arme, Haandled og Fingre strakt ned langs Siderne. Kroppens Vægt ført saa langt frem, at man hviler mere paa Fodbalderne end paa Hælene. Blikket rettet lige frem eller lidt højere. - Man maa passe paa, at Hovedet ikke glider frem, for saa rundes Ryggen gerne. Maven maa heller ikke gaa frem, da det medfører en for stærk Svejning af Lænden. Retstillingen er, naar den indtages rigtigt, som den gode Holdning, men noget strammere; men der bliver hos øvede Gymnaster en vis Frihed i den, som tager det stive bort og g $\emptyset \mathrm{r}$ den smuk og adskiller den fra den tunge, stive Retstilling, man ofte ser hos voksne Begyndere, f.eks. hos Rekrutter. Man hører undertiden Folk anke over, at Retstillingen og andre Stillinger i Gymnastikken ikke er naturlige. Men det skal de slet ikke være, tværtimod. Gymnastikken skal ikke være naturlig, men ved at forme og udvikle Legemet bidrage til, at Folks almindelige, daglige Bevægelser bliver smukkere og friere, end før de gik til Gymnastik. Det har aldrig været Meningen, at Retstillingen skulde føres med over i det daglige Liv, hvad enkelte i misforstaaet Iver har ment .

Som det ses af de sidste linjer blev retstillingen opfattet som den frie og den smukke krops kendemærke. Forfatteren (gymnastikdirektør Kåre Theilmann) mente åbenbart ikke, at retstillingen skulle overføres direkte til dagliglivet, men heri var han i modstrid med en anden gymnastikautoritet, statens gymnastikinspektør K.A. Knudsen, som betegnede retstillingen som »Legemets Normalholdning, udtrykt ved en bestemt gymnastisk Stilling« (Knudsen, 1916 (1930), s. 101). 
Citatets detaljerede kropsideal kan opsummeres på følgende måde: Ret ryg, hvælvet bryst, indadtrukket mave, løftet hoved og nakke, brystet længere fremme end underlivet, indtrukket hage, tilbagetrukkede og sænkede skuldre, arme, håndled og fingre strakt ud langs siderne, fremadrettet blik.

Det spørgsmål, som nu skal søges besvaret, er: Hvad kan de fremanalyserede kropsudtryk siges at betyde i et psykologisk perspektiv? Gymnastens stramme krop kan siges dels at fremkomme ved forsøget på at samle kroppen mest muligt. Ingen flagrende kropsdele! Alle kroppens lemmer samlet fast om torsoen! Dels krævedes der i retstillingsforskriften helt direkte en spænding af kropsdele som brystkasse og mave. En sådan stramning og spænding af gymnastens krop kan - sammen med den rette ryg - siges at implicere selvbeherskelse: $\operatorname{Man}(\mathrm{d})$ har i bogstaveligste forstand sig selv i stramme tøjler; i bundter af spændte muskler og kropsdele, man lader ikke ubehersket, dovent og slapt hovedet lude forover. (Reich, s. 138f, 145, 179 og 378).

Den hvælvede brystkasse var ikke kun et ideal i retstillingen, men gennemsyrede alle gymnastiske stillinger. F.eks. når der efter en bagudbøjning med medfølgende indånding fulgte en foroverbøjning med efterfølgende udånding, så måtte denne udånding ikke foregå som en krumning af kroppen, tværtimod skulle ryggen holdes helt strakt under udåndingen. Dette peger i retning af et vigtigt forhold. Skønt åndedrætsgymnastik var en vigtig del af den svenske gymnastik, skulle åndingsprocessen altid foregå som en udspiling af brystet via den øverste del af lungerne. Åndedrættet måtte ikke foregå som en udspiling af maven via mellemgulvsmusklens nedadgående bevægelse. Kropspsykologisk er dette af stor betydning, for det manglende dybdeåndedræt og den konstante udspiling af brystkassen vil bevirke, at gymnastens åndedræt bliver »fladt «, fordi brystkassen er spændt op af et lag af hårde muskler. Herved indesluttes hjerte og lunger, og følelser, der i vores kultur forbindes med dette område, kan ikke få frit udløb. Det største problem bliver at udånde helt, en handling som normalt associeres med »at give sig hen«. Følelser af hengivenhed, kærlighed, trang til at græde o.s.v. som normalt forbindes med hjerteregionen - og som for at flyde frit kræver en vis afslappelse $i$ overkroppens muskler - vil tendere mod at blive spærret inde bag dette brystmuskelpanser, og personen vil ofte føle en voldsom modvilje mod og angst ved at slippe dem løs.

Den spændte bugvæg holder indvoldene fast på plads, og de kan derfor ikke give ret megen plads for mellemgulvsmusklens nedadgående bevægelse, som følger af åndedrættets tryk på denne muskel. Resultatet bliver nemt, at åndedrættet bliver kort (i ekstreme tilfælde »stakåndet «), hvilket - i sammenhæng med den generelle muskelspænding - medfører en hæmning af alle »nedre « kropslige impulser, ikke kun genitale, men også anale og orale (sultimpulser fra maven).

Det fors $\varnothing \mathrm{g}$ på en dæmpning af gymnastens sanselige kropsstrømme, som her kan konstateres, var i en vis udstræning helt direkte formuleret i gymnastiklitteraturen. F.eks. agiterede gymnastikinspektør K.A. Knudsen i en artikel i bladet »Vort Hjem « for gymnastikkens velsignelser bl.a. ud fra den begrundelse, at det sikrede børnenes kyskhed (Vort Hjem, 1903, jvf. også Daneved, 1978, s. 61).

En mere subtil og mindre »tænkt « form for begrænsning af gymnastens seksuelle tøjlesløshed skete gennem gymnastikkens sammenkædning med renligheden og ikke mindst det kolde bad (Reiter, 1908, s. 6 og Theilmann, 1908, s. 43). 
»Badets Betydning for sjælelig Renhed« og dermed forbundet legemlig kyskhed kunne dog også i enkelte gymnastiktekster fremhæves helt bevidst (Sadolin, 1906, s. $65 f)$.

I begrundelserne for det kolde bad i folkeskolegymnastikken blev det slået fast, at:

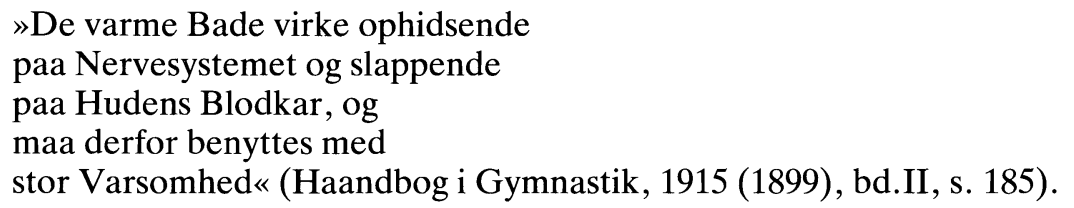

Analysen af forskrifterne for udformningen af gymnastens kropsdele kunne i princippet fortsættes næsten ubegrænset med inddragelse af hals, kæbe, baller o.s.v., o.s.v. De enkelte kropsdeles betydning bør imidlertid ikke ses isoleret, men bør analyseres ud fra et kropsligt helhedsbillede. Ud fra en sådan helhedsbetragtning springer det $\mathrm{i} \emptyset \mathbf{j}$ nene, at overkroppene generelt er mere udviklede og mere fremhævede end underkroppene, omend ikke så ekstremt som i moderne bodybuilding. Brystregionen er i bogstaveligste forstand pustet op. En sådan kropsstruktur kan karakteriseres som opblast, og »giver et generelt undtryk af en person som stræber opad, idet han gør sig selv større og højere end han virkelig er« (Kurz, 1976, s. 44).

Denne opadstræben kan altså forstås psykologisk som en hang til at komme fremad og opad i tilværelsen. Denne sammenhæng mellem det psykiske og det fysiske antydes i øvrigt i hverdagslige udtryk som »at skyde brystet frem« og »at mande sig op«.

Som det ses af retstillingsbillederne og -forskrifterne skulle gymnasten rette blikket fremad. Det fremadrettede blik kan ses i forbindelse med mere generelle tendenser $\mathrm{i}$ bondebevægelsens politiske og sociale profil. I bogen »I Broderskabets Aand « fra 1985 har Niels Ole Finnemann beskrevet den grundtvigianske bondebevægelsé som bærer af »fremskridtets ånd «. Denne ånd ser han som historisk karakteristisk ikke blot for den akkumulative kapitalistiske økonomi, men også for andre fremtrædende bevægelser og idéretninger som »det moderne gennembrud « og Socialdemokratiet, (s. 121) - og man kunne fristes til at tilføje sportsbevægelsen. Gymnastens hårde præstationskrop og hans blik, der skulle rettes væk fra støvlesnuden og den umiddelbare væren hen mod de fremtidige muligheders horisont, kan siges at være kropslige udtryk for bondebevægelsens fremadrettede dynamik. En dynamik som også viste sig i digteren Jens Christian Hostrups sang til den legendariske første forevisning af svensk gymnastik herhjemme. Det foregik på Vallekilde Højskole, og sangen hed »Vi fik ej under Tidernes Tryk, et bøjet Mod, en ludende Ryg«. Efter disse to første linjer fortsatte sangen således:

»vor kamp, vort kald, hvad bære vi kan,

end ligger gemt under synskredsens rand.

End vor røst er uden magt

og vor dåd uden hjem,

og om os er alting sagt

med det ord: vil vil frem! Fremad efter livets kranse!

tid har vi ej til at standse!

(Korsgaard, 1982, s. 82f) 
Længslen efter fremtidens land og den rastløst fremadrettede dynamik, som ligger i denne sang, såvel som i forskrifterne til gymnastens kropsudtryk, modsvaredes imidlertid ikke af en bevægelsesmæssig dynamik. Hvor gymnastens modbillede - sportsmanden - krummede ryggen og fór fremad i et forsøg på at nå et mål hurtigst muligt uanset om det var et fodboldmål eller et kapsportsmål - stod gymnasten næsten stille, og bevægede sig oftest kun på den plads, han nu engang havde fået.

Fremfor at udstråle dynamisk fremadstræben signalerede den mandlige gymnast gennem sine bevægelser en form for maskulin urokkelighed og fasthed. Den traditionelle svenske gymnastiks forhold til »fremskridtets epoke «må derfor karakteriseres som tvetydigt, som en blandingsform af dynamiske og statiske elementer. Kritikken mod den svenske gymnastik satte netop ind overfor dette forhold, og op igennem det 20'ende århundrede erstattedes den svenske stillingsgymnastik da også efterhånden af en mere dynamisk bevægelsesgymnastik, som jeg senere vil komme ind på.

\section{Kropslig og social rejsning}

Hvis en enkelt kropsdel nogensinde har spillet en central rolle for en hel bevægelses ideologi, må det være den svenske gymnastiks betoning af den rette rygsøjle. Vi har allerede i retstillingsforskriften set, hvordan »Rygradens Krumninger (skulle) rettes ud saa meget som muligt«. Og dette gjaldt ikke kun den nedre del af rygs $\varnothing j$ len, men også halshvirvelsøjlen. Nu havde det egentlig et smukt sundhedspædagogisk formål at rette ryggen ud, for det kunne angiveligt modvirke de i tiden udbredte symptomer på en overdreven svejning af lænden og krumning af halshvirvelsøjlen. Man kan dog tvivle på, hvorvidt en helbredelse for disse lidelser kunne foregå ved en simpel og direkte g $\varnothing$ -
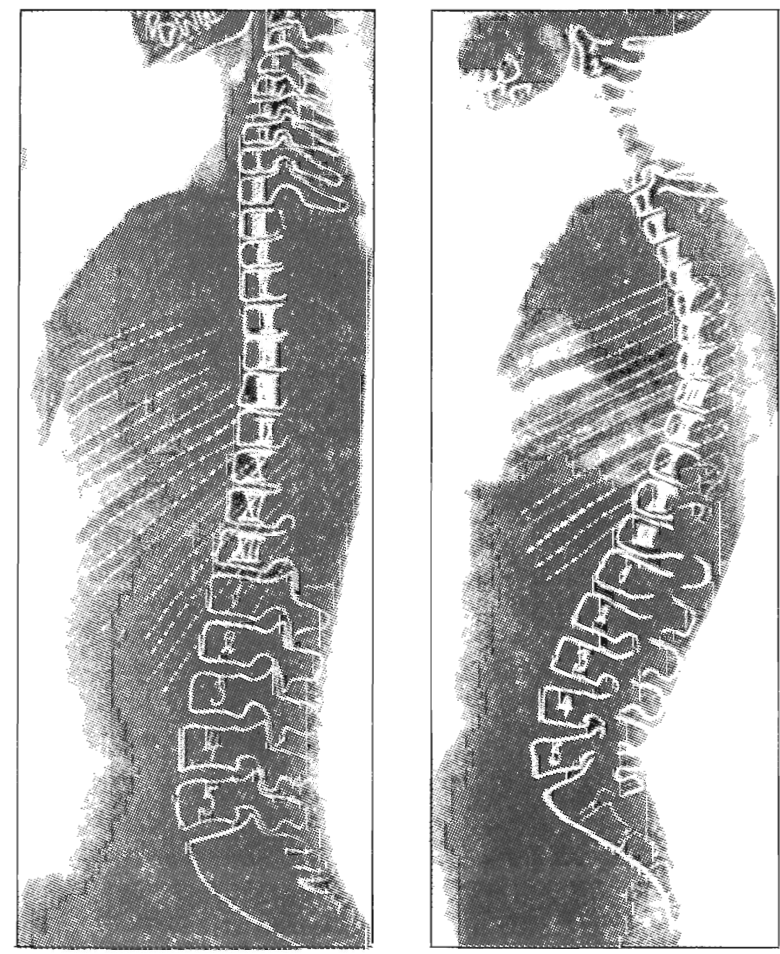

Gymnastikinspektør K.A. Knudsen må have haft en abnormt udviklet dreng med ryg som en lineal som forlaeg for det venstre-røngenbillede, der viser den »normale retstilling « versus det højre billede af den angiveligt rundryggede dreng. Måske har Knudsen blot haft en "heldig hånd", da han tegnede rygraden ind på rongenfotografiet?

Kilde: Knudsen, 1930, s. 106. 
ren det modsatte - altså fra krumning til afretning. Og det er også svært at se, hvorfor den ekstremt rette ryg skulle gøres til et ideal for de, som ikke led af de nævnte sygdomme.

Sådanne indvendinger forbigår imidlertid den sandsynligvis vigtigste (ofte ubevidste) dimension i idealiseringen af den rette ryg: At ranke sig var nemlig ikke blot en fysisk ønskværdig proces, men også et udtryk for moral; den ranke svenske gymnast blev ikke kun fysisk højere ved at rette sig op, han blev også moralsk set et højere væsen! Dette angives allerede i Hostrups føromtalte sang, hvor »et bøjet Mod «sidestilles med »en ludende Ryg «. Læreren til det hold, som introducerede den svenske gymnastik i Danmark, N.H. Rasmussen, lod rejse et gymnastikhus i København og ovenover indgangsportalen fik han indmejslet ordene: »Ret ryggen og tal Sandhed «. Den rankede ryg var altså både et tegn på mod og sandhedssøgen. Som et ekstremt eksempel på en helt bevidst sammenkobling af den »gode « kropsholdning og den »gode « mentale holdning kan nævnes dette citat fra »Gymnastisk Selskabs Aarbog« (1906, s. 78):

»Et folk, der har Dristighed samt de nærtbeslægtede Egenskaber Højsindethed og Trofasthed som Karakter-Mærke vil ogsaa som Helhed have en god Holdning, medens fejge, lavttænkende og lumske Folk gennemgaaende bliver nogle Grimrianer .

I den svenske gymnastik blev den rette holdning imidlertid ikke blot anset for (moralsk) god og sund, men også for smuk (jvf. f.eks. Knudsen, 1895, s. 5). Den svenske gymnastiks fascination af retlinetheden standsede ikke ved hudens overflade, men kendetegnede mere bredt kroppens organisering i rummet: Også bevægelserne foregik nærmest efter en lineal, gymnasterne stod derudover på snorlige rakker og øvelserne blev ikke foretaget udendørs i naturens mere »krumme« og uoverskuelige univers, men indend ørs i symmetriske og retvinklede halbygninger (Eichberg og Jesperson, 1986, s. 203ff). At det ikke blev anset for indespærrende at være indenfor i gymnaśtikhallen skal dog ses på baggrund af bøndernes daglige færden i det fri. De havde ikke som de civilisationstrætte byboere nogen grund til at længes efter naturen. Måske havde de tværtimod trang til at søge i ly i en tryg hal. Alt i alt vil jeg karakterisere den skønhedsdyrkelse, som den svenske gymnastik byggede på som en fascination af de rette linjers astetik, en retlinethed som signalerede orden, planmæssighed, selvkontrol og disciplin.

Den svenske gymnastik byggede altså essentielt på en rejsning af ryggen, og denne retten sig op kan også siges at have en socialpsykologisk dimension: For bønderne kan den rette ryg siges at have symboliseret afkastelse af et socialt åg; igennem århundreder - og stadig omkring århundredeskiftet - var bonden af herremanden, præsten og byernes overklasse blevet anset for at være et laverestående væsen (Dansk Socialhistorie, bd.5, 1982, s. 93 og Korsgaard, 1982, s. 101f). Denne massivt undertrykkende ideologi har givetvis sat sig som en underlegenhed i mange bønder. Denne underlegenhed, og i det hele taget opfattelsen af at bønderne tilhørte underklassen, kan siges at have en kropslig dimension. For herremanden/godsejeren var ikke bare overlegen i kraft af sin sociale position, men forsøgte sandsynligvis også rent kropsligt at hævde sig gennem allerede fra 1400-tallet at gennemgå en civilisationsproces, der omfattede en opretning af ryggen (Vigarello, 1978 og Centring, 1982/83, s. 117-137). Ud fra adelsmandens perspektiv måtte bondes (af hårdt legemligt arbejde krummede) ryg givetvis signalere usømmelighed, ubeherskethed, uciviliserethed, og ja, i bogstaveligste forstand, underdanighed. Det skal derfor givetvis netop ses i dette perspektiv, at den svenske gymna- 
stik i datiden kunne opfattes som prentende et »Adelsmærke« på bondens krop (Korsgaard, 1982, s. 105).

Bøndernes rejsning af kroppen i den svenske gymnastik kan også tolkes på baggrund af bøndernes sociale rejsning fra omkring 1880'erne. I slutningen af 1870 'erne løb landbruget efter den lange givtige kornsalgsperiode ind i en afsætningskrise. Denne krise var en afgørende trussel mod bøndernes eksistens som en stærk og selvstændig klasse i det danske samfund. Svaret på udfordringen blev det internationalt geniale: Andelsbevægelsen, som bredte sig til hele landbrugssektoren i stort set samme takt som den svenske gymnastik vandt udbredelse (Daneved, 1978, s. 16ff). Når man forestiller sig det ekstreme pres i retning af at kunne omstille sig, undgå deklassering og klare krisens tryk, som perioden bød på, bliver idealiseringen af den spændte, stramme, ranke krop i den svenske gymnastik pludselig meningsfuld. Man kunne næppe forestille sig en blød, afspændt og rytmisk »vandmands«-gymnastik vinde frem i en periode, der krævede så stor evne til selvkontrol og fasthed som 80'ernes landbrugskrise. Dette skal dog ikke opfattes som om, den svenske gymnastik var et direkte og bevidst svar på en økonomisk krise, men er et argument for, at idrætskulturen med udbytte kan ses i sammenhæng med produktionskulturen. Tværtimod er det min opfattelse, at den svenske gymnastik var en dynamisk og samfundsforandrende kraft, som altså ikke bør opfattes som en refleks af materielle forhold.

Et andet eksempel på en sådan sammentænkning af den økonomiske og kropslige kultur er det fælles mønster i andelsbevægelsens og gymnastikkens betoning af fællesskabet. I modsætningen til byernes liberalisme og individualisme og sportsbevægelsens stærke betoning af enkeltmandsdygtighed, blev der i den svenske gymnastik lagt vægt på holdets dygtighed som et hele, ligesom der i andelsbevægelsen blev stemt efter hoveder ikke efter høveder (Korsgaard, s. 91ff). Den svenske gymnastiks kollektivisme bør dog ikke romantiseres, al den stund den byggede på en meget høj grad af disciplin med lederens kommandoråb som egentlig styrende redskab.

På samme måde bør idéen om én mand én stemme heller ikke overskygge for det faktum, at bønderne i andelsperioden faktisk fjernede sig socialt fra husmæendene. Således syntes de sociale skel mellem gårdejere og husmænd (og landarbejdere) netop at blive klare og tydelige i løbet af 1880'erne (Daneved, 1978, s. 61), og antagelig skete der i den forudgående periode en både relativ (i forhold til gårdmændene) og absolut forarmelse af husmændene m.fl. (Boel, 1985, s. 109. Tallene går til ca. 1871). Bøndernes kropskulturelle rejsning skal derfor ikke blot ses som et forsøg på en profilering opad (mod godsejerne og de store proprietærer), men også som en afgrænsning nedad: Husmændenes sønner og døtre havde givetvis hverken tid eller råd til at dyrke gymnastik på linje med gårdmandsfamiliens unge. I hvert fald kan Jens Boel i sin bog om »Husmænd og landarbejdere i Danmark « (ca. 1848-75) konkludere, at:

»Trods fripladser var højskolen altså i midten af 70'erne således fortsat fremfor alt en skole for gårdmandsbørn. Den materielle skillelinje i bondestanden ledsagedes af en immateriel« (Ibid., s. 108).

Skarpt trukket op blev husmændene således givetvis ved med i bogstaveligste forstand at slide sig en pukkel til i modsætning til bonden, der rankede sig ikke kun i forhold til godsejerne, men også til den egentlig underklasse på landet, husmændene. Denne kropslige distanceringsproces understregedes i øvrigt også af de højde- og vægtmæssige forskelle mellem husmands- og gårdmandsbørn. Fattigdom og mangelsyg- 
domme bevirkede, at gårdmandsbørnene sandsynligvis var i gennemsnit $2,5 \mathrm{~cm}$ større og 2-5 pund tungere end husmandsbørnene (Ibid, s. 104).

Endnu en nærliggende mulighed for at sammentænke gymnastikken med den øvrige samfundsudvikling skal nævnes. Bøndernes kropskulturelle og sociale rejsning blev nemlig fulgt af en politisk rejsning vendt mod det $h ø j$ reorienterede Estrupregime. Den "svenske « gymnastikbevægelse var nemlig i sammenhæng med skyttebevægelsen på landet en mere eller mindre direkte formuleret trussel mod Estrups regering. Som sådan blev den i øvrigt ofte opfattet af den danske højrefløj (Daneved, 1978, s. 61-69 og 75-89 og Korsgaard, 1982, s. 71-80 og 88-90).

Gymnastik- og skytteforeningerne kan altså siges at have et islæt af kamporganisation; og den svenske gymnastiks stramme kropsideal bliver mere forståeligt ved en inddragelse af bøndernes politiske situation. Faktisk havde den svenske gymnastiks kropssprog et stærkt militaristisk præg, hvilket allerede viser sig i retstillingen, og interessant nok blev den svenske gymnastik også indført indenfor mange europæiske landes militær inklusive det danske (Müller, 1927, s. 14 og 32).

Konkluderende vil jeg sige, at den svenske gymnastik i bund og grund må ses som et maskulint kropssprog med klare militære træk. Dette kropssprog skal absolut ikke opfattes som biologisk givet, men som udtryk for kønskulturelle normer. Kvinder blev jo ikke udskrevet til militærtjeneste med en deraf følgende formgivning af deres kropsudtryk, og i skolerne betød den store mangel på kvindelige gymnastiklærere, at kvinderne igennem det 19. århundrede givetvis i langt mindre grad indgik i gymnastiske kropsformningsprocesser, der kunne påvirke det kvindelige kropssprog i retning af retstilling, opspænding og holdningskorrektion. Det skal dog tilføjes, at vi ved meget lidt om den (forskellige) kropslige socialisation i by- og landbokredse. Givet er det dog, at 1800-tallets traditionelle gårdmandsdatter eller -kone har været langt mere åben-overfor at udtrykke sig med voldsomme, stærke og svedfrembringende bevægelser. Ifølge et gammelt ord fra landet, skulle man »skue en Pige i et Dejgtrug og.ikke i en Springdans« (Faye Jakobsen og Løkke, 1986, s. 117). Det modsatte kunne givetvis siges for borgerskabets kvinder.

Dette skal dog ikke tages til indtægt for, at landbokvinderne ikke kunne føle en befrielse ved at deltage i den svenske gymnastik. Gymnastikken kan ikke reduceres til, hvad en »kropslig adfærdsanalyse « kan give. For det første har det givetvis kunnet give mange kvinder et løft at få lov til at udføre »maskuline bevægelser «. For det andet har den stemning, som har omgærdet den svenske gymnastik, givetvis været af lige så stor betydning som $\emptyset$ velserne i sig selv. Den svenske gymnastik var jo led i en religiøs og åndelig, grundtvigiansk vækkelse af gårdmandsstanden, hvilket sandsynligvis har givet sig udtryk i en meget stærk entusiasme og fællesskabsfølelse i gymnastikken. Dertil kom forskellige ritualer, der fastholdt den grundtvigianske bevægelses religiøse og socialt fremadskuende ånd. Som nævnt sang gymnasterne under ind- og udmarch $i$ timerne, og i taler og sang blev den grundtvigianske forbindelse mellem hånd og mund - krop og ånd - fastholdt (Korsgaard, 1982, s. 80ff).

Samtidig skal det ikke glemmes, at gårdmandsdøtrene i perioden før og efter århundredeskiftet oplevede en delvis domesticering, d.v.s. de gik fra at være medansvarlige for produktionen af livsnødvendigheder til mere og mere at tage sig af funktioner i forbindelse med gårdhuset alene, mens gårdmanden generelt stod for produktionen til andelsmejeri o.s.v. Tidligere havde kvinderne stået for en stor del af forarbejdningen af 
produktionen, en funktion der nu i stadig større omfang blev overtaget af andelsproduktionsstederne (Faye og Løkke, 1986, s. 36). I denne situation har deltagelsen i en gymnastikform på stort set de samme præmisser som mændene givetvis virket dragende på mange kvinder.

Den svenske gymnastiks islæt af mandekultur understreges også af mændenes faktiske kvantitative dominans i de frivillige gymnastikforeninger, hvor der dyrkedes svensk gymnastik. I 1907 gymnasticerede ca. 33.000 mennesker i De danske Skytteforeninger, herunder ca. 20.000 mænd, ca. 8.000 kvinder og ca. 5.000 drenge. På højskolerne blev der i perioden 1907-08 undervist ca. 7.000 elever, sandsynligvis lige mange af begge køn (Theilmann, 1908, s. 50). Næsten alle billeder og tegninger af »svenske« $\emptyset$ velser blev endvidere udført af mænd.

Til dette »maskuline billede« af den svenske gymnastik kommer, at systemets skaber, P. H. Ling (1776-1839), havde udviklet sin gymnastik som en mandegymnastik. Den svenske gymnastikhistoriker Claes Annerstedt konkretiserer dette således:

»Gymnastikken blev fra begyndelsen kun udøvet af mænd. Den blev ledet af mænd og var tilpasset mænd« $(1983$, s. 71).

Ikke desto mindre overførte hans søn, Hjalmer Ling, den militært prægede lingske spændingsgymnastik (som dog kun var en del af P.H. Ling's gymnastiske værk) på kvindegymnastikken, dog med enkelte vigtige modifikationer. F.eks. blev hård konditionsog styrketræning samt direkte militære øvelser udeladt (Ibid, s. 94), hvilket også gjaldt for Danmark omkring århundredeskiftet (Theilmann, s. 40). De kvindelige gymnasters fors $\emptyset \mathrm{g}$ på i begyndelsen af det 20'ende århundrede at udvikle en selvstændig kvindegymnastik, som var mere i pagt med normerne for deres kulturelt betingede kropslige udtryksformer, må ses på baggrund af det ovenfor beskrevne stærke maskuline element i århundredeskiftets lingske gymnastik.

\section{Kropstugt i skolen}

Ikke kun indenfor højskolerne, skytteforeningerne og hæren gik den svenske gymnastik sin sejrsgang i begyndelsen af det 20'ende århundrede. Også indenfor den danske folkeskole blev der fra århundredeskiftets begyndelse indført en gymnastikform, der i vid udstrækning byggede på de »svenske« principper. Dog i pigeskolerne mødte den svenske gymnastik i hvert fald i begyndelsen af århundredet »sejg Modstand « fra Poul Petersens gymnastiksystem (Müller, 1927, s. 32). Og endnu i 1908 var gymnastik ikke et obligatorisk skolefag for piger i alle skoler (Theilmann, 1908, s. 40).

Problemet med den svenske gymnastik var for mange børn, at det præg af vækkelse og stemning, som havde givet landboerne et løft, når de dyrkede svensk gymnastik, nu blev skrællet af til fordel for en ren sundheds- og disciplineringspædagogik. (Haandbog i Gymnastik, 1899, bd.I, s. 2ff, 60ff og 108ff).

Gymnastikautoriteterne var udmærket klar over, at eleverne ofte opfattede den svenske gymnastik som kedelig, men overfor denne indvending blev det slået fast, at målet jo ikke var »at more, men at opdrage de unge (Ibid, bd. 2, s. 5). Det giver sig selv, at den halvmilitære svenske gymnastik for piger såvel som for drenge måtte være genstand for en stærk modvilje fra mange elevers side. En sådan modvillighed eller egentlige modstandsform er imidlertid, såvidt jeg ved, ikke dokumenteret. Skolens 
kropsformning af eleverne blev imidlertid næppe først og fremmest udvirket af gymnastikken, men af selve skolens boglige præg: at sidde stille på en bænk en hel dag må have føltes ekstremt disciplinerende for en arbejder- og bondeungdom, som var opvokset med livet på gaden eller i naturen og med (børne)arbejde henholdsvis i byjobs og $\mathrm{i}$ landbrugsproduktionen.

Gennem de detaljerede forskrifter for kroppens bevægelser og form i skolegymnastikken (Ibid, s. 69ff og Knudsen, 1930, s. 101ff) kan vi få et meget detaljeret billede af det $\varnothing n s k e d e$ ideal for det unge menneskes fysiske fremtrædelsesform i perioden. Et ideal som stort set stemmer overens med det i den foregående analyse fremdragne ideal for den »svenske « gymnasts krop. Samtidig blev der dog tilføjet nogle mere dynamiske, hurtige og fremadrettede $\varnothing$ velser under betegnelsen »Den anvendte gymnastik «. Under denne betegnelse gemte der sig (foruden forskellige gamle lege) sportsdiscipliner som boldspil, kapløb, kapgang, tovtrækning, bueskydning og svømning. Pigerne skulle dog ifølge håndbogen for de danske folkeskolegymnastiklærere ikke dyrke kricket og fodbold (Haandbog, bd.II, s. 6). Gymnastikken skulle grundlæggende være ens for begge de to $\mathrm{k} \emptyset \mathrm{n}$, men eftersom kvinden blev anset for svagere end manden og for at have et »mere let og påvirkeligt Nervesystem«, blev $\emptyset$ velser der krævede særlig styrke, anspændelse og mod ikke anbefalet for pigerne (Haandbog, Bd.I, s. 30 og 4).

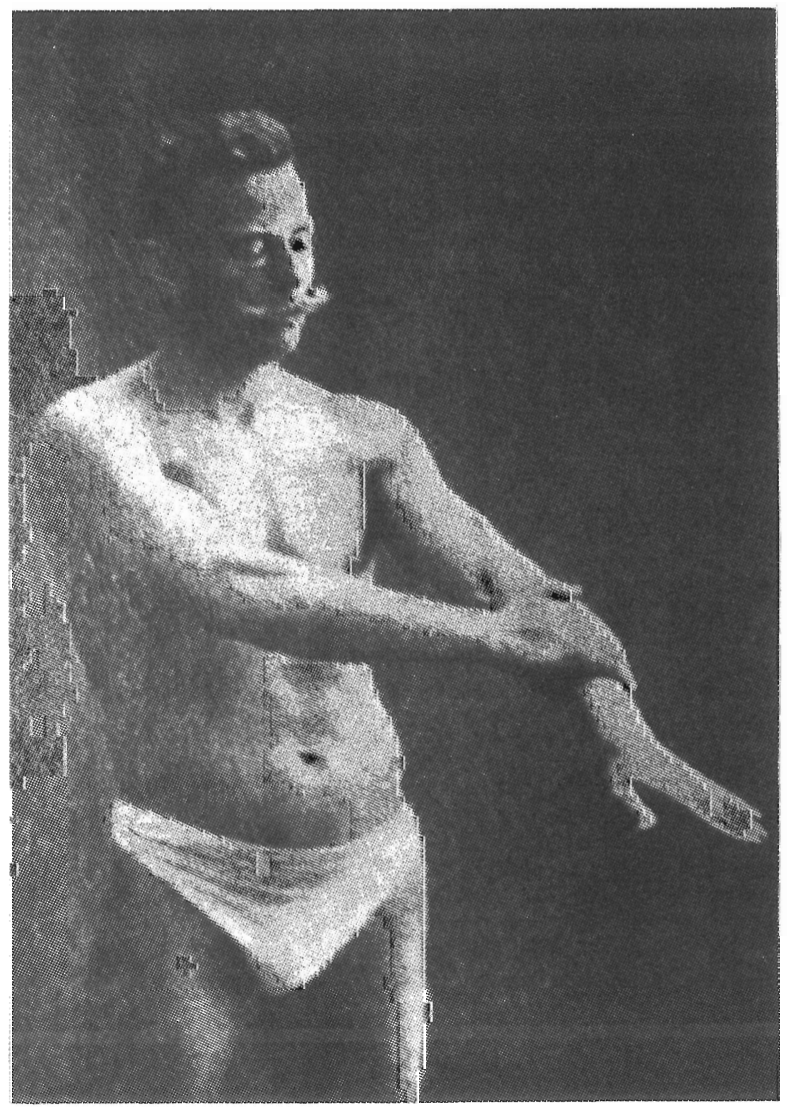

I modsatning til langt de fleste mand, som omkring århundredeskiftet blev afbildet på fotografier, var I.P. Müller ikke bange for at slappe af $i$ ubeskaftigede muskler, lade maven falde afslappet frem og gynge »feminint $i$ hofterne. Kilde: Müller, 1905, s. 94. 


\section{P. Müller}

I.P. Müller er givetvis den dansker, der har opnået størst internationel udbredelse med et gymnastiksystem. Hans hjemmegymnastikbog, »Mit System « fra 1904, blev således oversat til 25 sprog og trykt i 1,5 mill. eksemplarer (Eichberg og Jespersen, 1986, s. 212). Til forskel fra den svenske gymnastik byggede Müller i vid udstrækning på afspænding af kroppen, f.eks. anbefalede han dybdeåndedræt, hvor maven bulede ud (Müller, 1915). En attitude, der var helt i modstrid med både den svenske gymnastik og sportsbevægelsens mandeideal.

Müller tordnede da også mod den svenske gymnastik, hvis holdningsideal med brystet frem og maven ind han betegnede som en »kropsduefigur« (Müller, 1927, s. 7). I bogen »Hvad fejler vor Ungdoms fysiske Opdragelse « fra 1927 lagde Müller ud med allerede på første side at kritisere »den overdrevne Stivhed i Holdningen hos svenske Gymnaster og hos militære «, og han opsummerede disse retninger indflydelse omkring århundredeskiftet på følgende måde:

»Det blev almindeligvis anset for smukt og smart at spadsere omkring med fremskudt Bryst og konstant indtrukken Mave, ligeledes med en Mængde.Muskler unødvendigt strammede« (s. 7).

I sin konsekvente kritik af kropslige pansringsprocesser og åndedrætshæmninger var I.P. Müller en interessant forløber for Wilhelm Reichs teori om muskel- og karakterpansret (Reich, 1942), dog uden dennes koblinger mellem psyke og krop. Såvidt jeg har kunnet konstatere, var Müller også den første danske gymnastikpædagog, der indenfor de sidste 100 år helt bevidst arbejdede med et afspændingsbegreb. »Spændingens og afspandingens histore « kan måske blive en givtig fremtidig indfaldsvinkel til studiet af vigtige kropskulturelle og bredere samfundsmæssige udviklingstendenser?

Müller fandt sit store ideal blandt de klassiske græske statuer, især Apoxiomenos af Lysippos. På sit skrivebord havde han en statue af Apoxiomenos, og det morede ham at lade sine elever og besøgende betragte et par statuetter af Apoxiomenos og Antonius fra siden, fordi:

»Uagtet de sikkert repræsenterer de mest fuldkomne Mandsskikkelser Verden endnu har set, tager de sig dog - sammenlignet med den gængse, moderne Retsstilling - rundryggede ud, og Bugen stikker en lille Smule mere frem end Brystet « (Ibid. s. 8).

At Müllers kritik af det maskuline ideal om at være fast og hård i musklerne og trække maven ind har relevans den dag i dag, kan man forsikre sig om blot ved at se på præsentationer af herreundertøj i de store varehuses kataloger!

Ét af Müllers smertensbørn var skolen. I den føromtalte bog havde han f.eks. et omfattende kapitel med titlen »De værste Mangler ved den danske Skolegymnastik «, (s. 37-45), og han berettede i bogen om et mislykket fors $\emptyset \mathrm{g}$ på i 1921 at formå de danske skoleautoriteter til at give hans gymnastik en chance i den danske skolegymnastik. Opfordringen, som var formet som et brev til undervisningsministeriet, blev overgivet til gymnastikinspektøren K.A. Knudsen (Sic!) og sandsynligvis arkiveret lodret (Ibid. s. 33-36). 


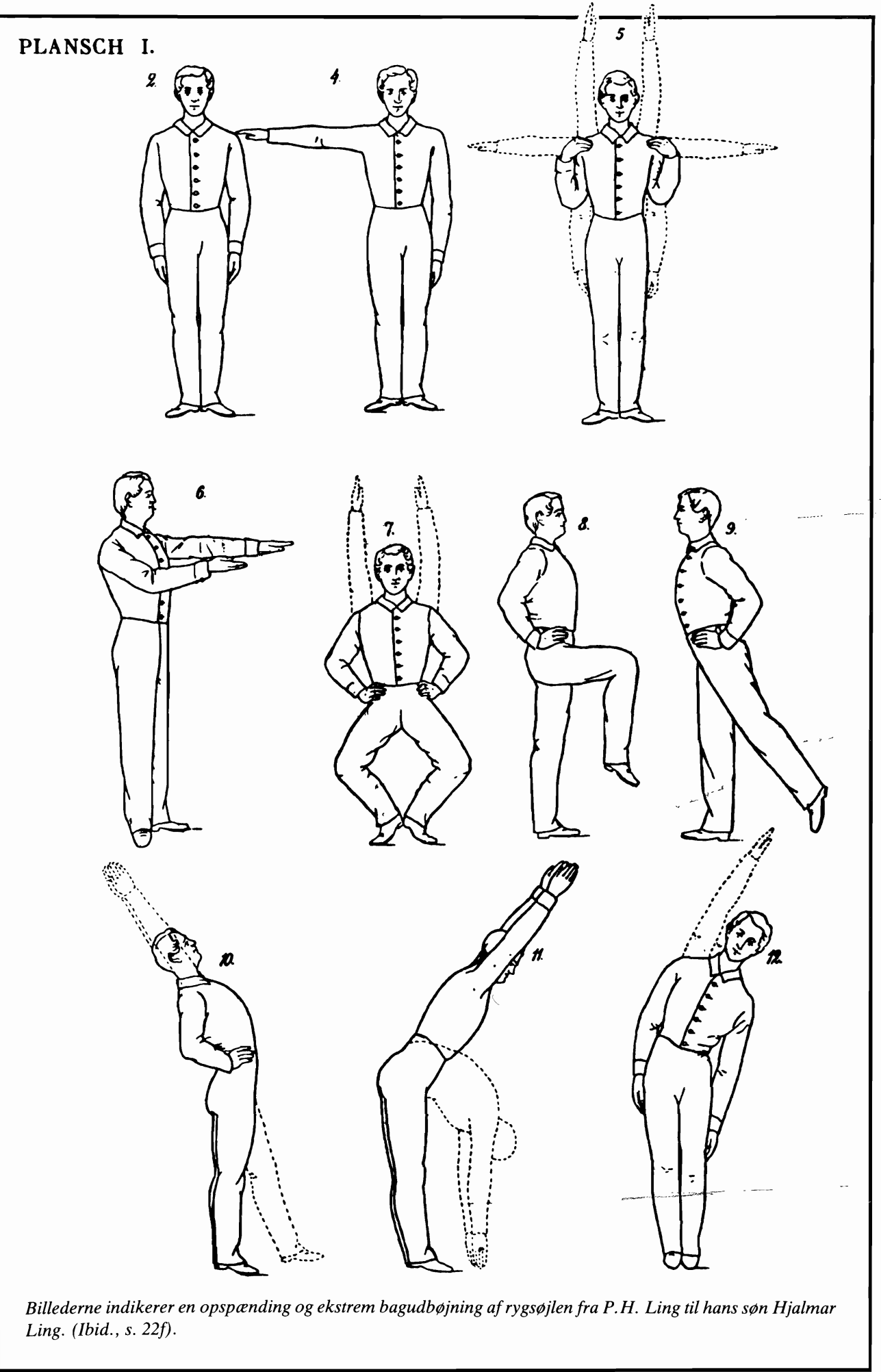



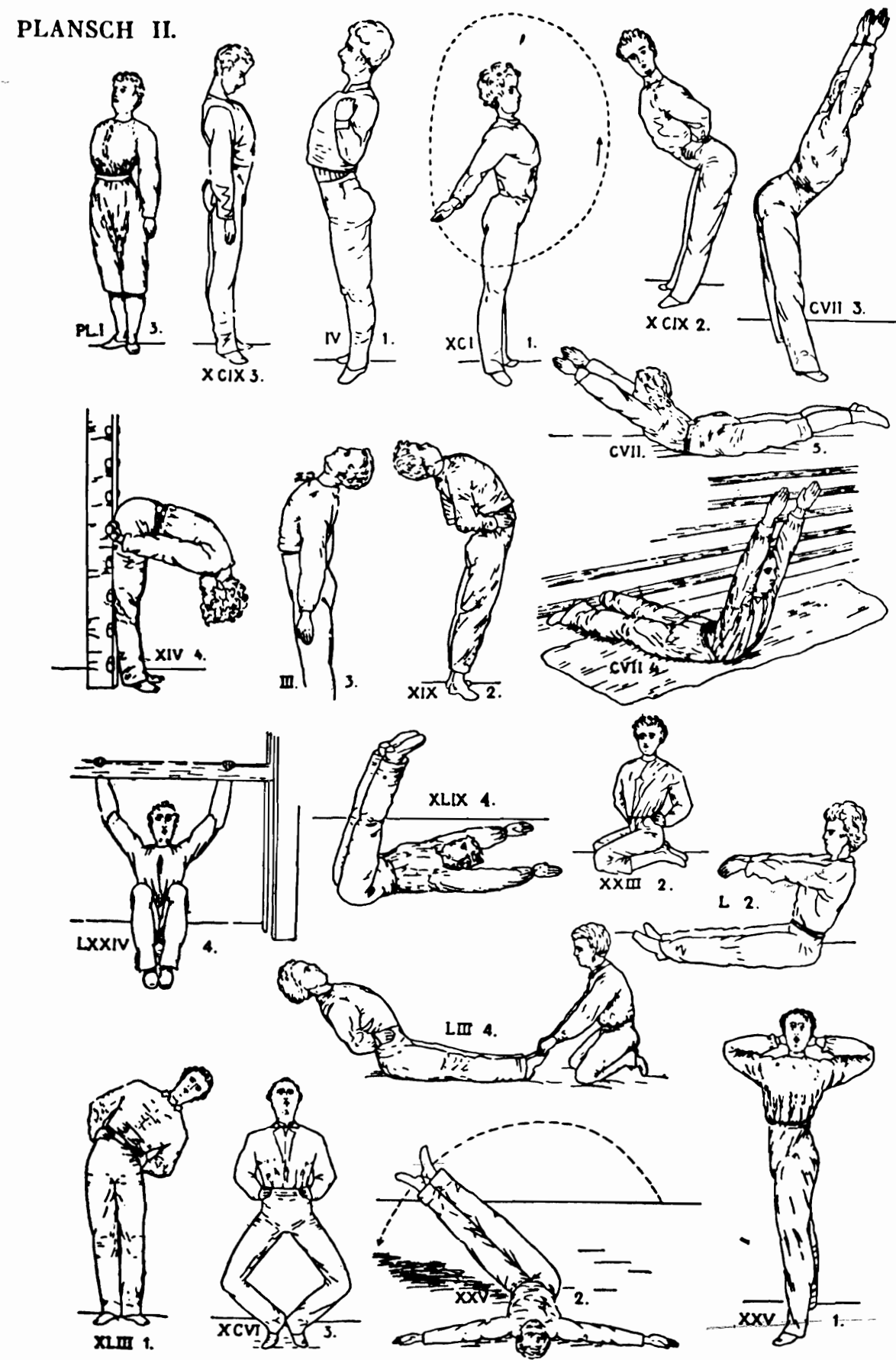

Måske er det ikke korrekt at betegne P. H. Lings gymnastik som spandingsgymnastik. I hvert fald betonede inspektøren for de svenske folkeskoler I. G. Thulin i 1924 (s. 11), at afspandings $\emptyset$ velserne havde varet med hos Ling, men $i$ de følgende 100 år varet draget ned $i$ "glömslans djupa Källarvalv«. Spørgsmålet er så, hvorfor de forsvandt! 
Müllers bestræbelser var imidlertid ikke et isoleret fænomen i den danske kropskultur. I 1927 kunne han således konkludere, at noget nyt var sket med den svenske gymnastik med udgangspunkt i Sverige og Finland, hvor både mandlige og kvindelige gymnastikpædagoger:

»Frigjorde sig fra den overdrevent stive Holdning, tillod Afslappelse af ubeskæftigede Muskler og lod livlige, ofte gentagne Bevægelser afløse de tidligere saa dominerende stivnede Stillinger«. (Ibid. s. 31).

Og hermed er vi allerede et lille stykke inde i historien om den selvstændige kvindegymnastik.

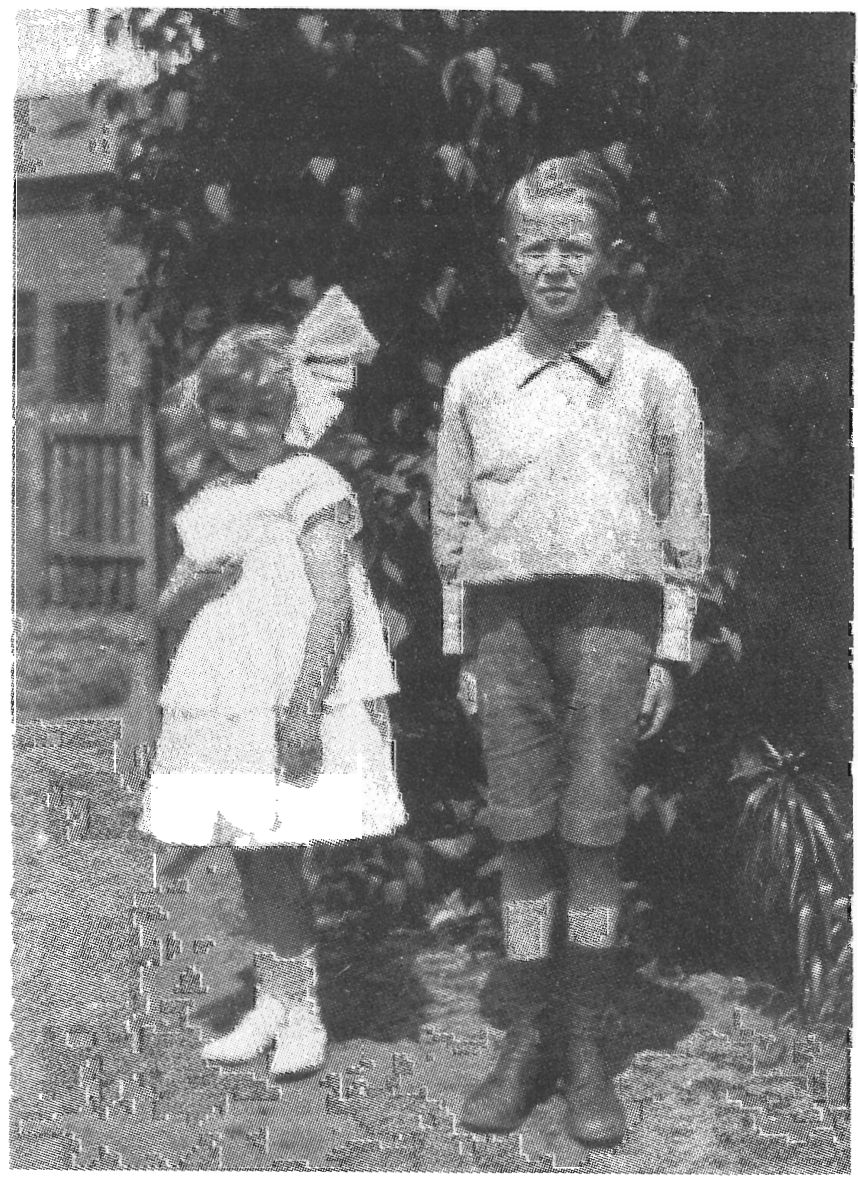

Portratfotografi af dreng og pige ca. 1920. Begge søger de givetvis at vise det bedste af sig selv, hvilket for pigen implicerer en blod Sform $i$ kropsholdningen, mens drengen står $i$ stram retstilling. Kilde: Fausing (m.fl.), 1984. 


\section{Den selvstandige kvindegymnastik}

Udviklingen af den selvstændige kvindegymnastik i Norden kan siges at være blevet indledt med den finske gymnastikpædagog Elli Bjørkesteins opvisning med sit kvindehold ved olympiaden i Stockholm i 1912. I et af den svenske gymnastiks centrale organer, Gymnastisk Selskabs Aarskift blev denne opvisning da også oplevet som et brud med den etablerede gymnastik, et brud som tidsskriftets observat $\varnothing \mathrm{r}$ ved OL, lægen V. Harsløf, ønskede velkommen i varme vendinger (1912, s. 156ff). Harsløf fandt, at der over Bjørksteins finske gymnaster var en »følelsesbetonet Ynde... uden hvilken Kvindegymnastikken bliver en Uhyrlighed « (Ibid. s. 158). Det nye i Bjørksteins gymnastik var en kritik af den svenske stillingsgymnastik og en betoning af bevægelsen. Dertil kom en rytmisk udførelse samt gymnastik til musikakkompagnement (Annerstedt, 1983, s. 80).

En anden nordisk kvindelig gymnastikpædagog, som fik stor indflydelse på den nye kvindegymnastik, var svenskeren Elin Falk (1872-1942). Falks gymnastik byggede på en bevægelsesmåde med mindst mulig spænding og totale, rytmiske bevægelser, som gennembølgede hele kroppen. Skønt både Bjørkestein og Falk var uddannede på den svenske gymnastiks højborg i Stockholm, det centrale gymnastikinstitut, mødte de hurtigt kraftig modstand fra de ortodokse svenske gymnastikpædagoger. Om der har været tale om en lignende modstand mod de nye afspændingspædagogiske og rytmiske kvindegymnastikformer i Danmark er svært at sige. I K.A. Knudsens undervisningsbog for seminarierne blev der i 2. udgaven fra 1922 direkte argumenteret for, at der ikke var sket væsentlige nyudviklinger på gymnastikkens område. I 3. udgaven fra 1930 var Elli Bjørksteins idéer imidlertid slået igennem både i undervisningsmåden og i øvelsesstoffet, og Bjørksteins stillingsgymnastik og selvstændige kvindegymnastik blev nu rost i høje vendinger (Knudsen, 1930, s.IXff). Overfor den nye plastiske og stærkt æstetiske tyske udtryksgymnastik slog K.A. Knudsen dog syv kors for sig, idet han konstaterede, at en sådan »Unatur« heldigvis ikke havde slået rødder i Danmark (Ibid, s. XV).

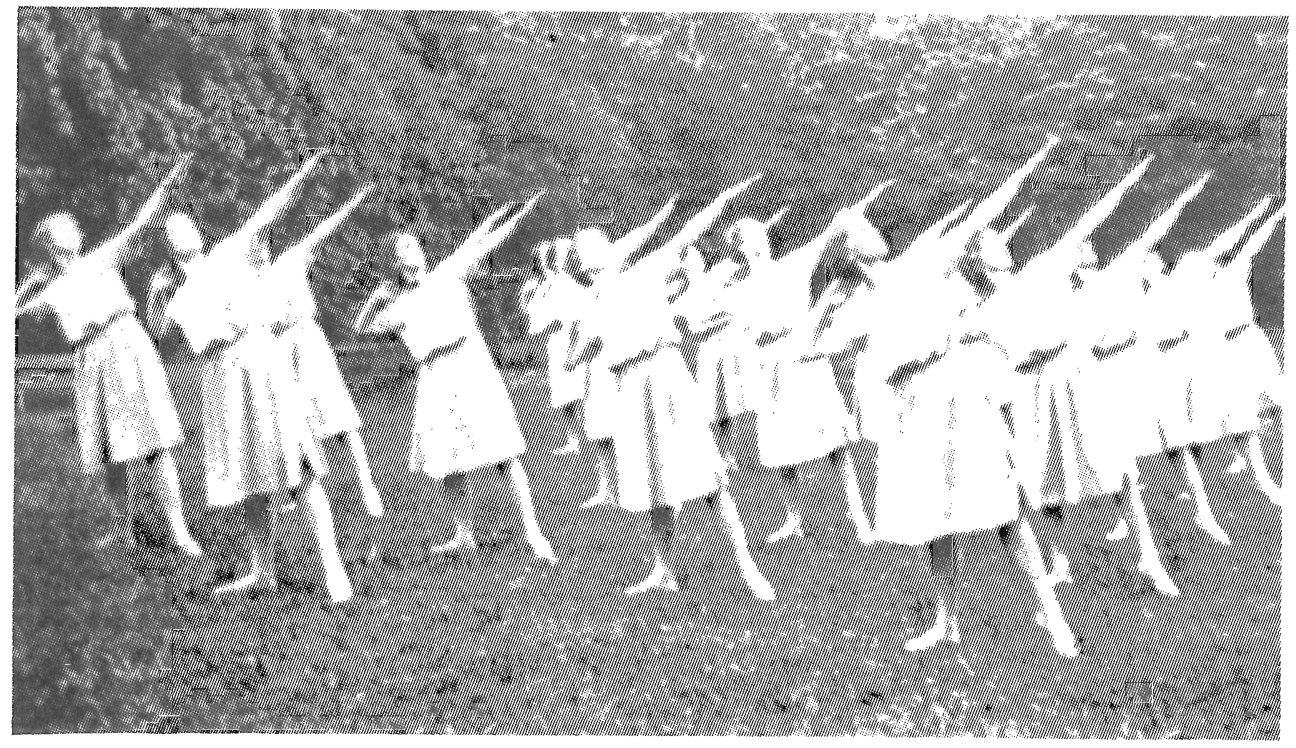

Bjørksteingymnastik, afspandt med ranke rygge.

Kilde: Korsgaard, 1982, s. 236. 
Men sluserne var nu åbnet, og den tyske Medaugymnastik, med sin betoning af fortløbende bevægelser og hofteledene som centrum, vandt indpas i Danmark fra midten af 30'erne (Korsgaard, 1982, s. 246). Fra 1950'erne og frem fik Medaugymnastikken og den rytmiske gymnastik overtaget i forhold til den svenske kvindegymnastik (Ibid., s. 250). Lang tid før dette havde Snoghøjpigerne imidlertid taget tråden fra Bjørkstein op ved at dyrke et spændstigt og let bevægelsesmønster (Ibid., s. 235). Denne gymnastikforms rødder i den traditionelle svenske gymnastik viste sig imidlertid ved dens reaktion på de sydlandske gymnastiske vinde, der nu blæste fra byerne, og som af én af grundlæggerne af Snoghøjskolen, Jørgine Abildgaard, blev karakteriseret som en afslappet, vandmandsagtig kvindegymnastik (Ibid., s. 243). På Snoghøj dyrkedes den ranke holdning, og det var ikke mærkeligt, at f.eks. Labangymnastikken som accepterede alle mulige former for krumning af kroppen, kunne vække anstød hos fortalerne for den rette gymnastikholdning.



Medaugymnastik. Landsstovnet $i$ 1954. Nu er det tilladt at krumme ryggen! Kilde: Korsgaard, 1982, s. 246.

Kvindegymnạstikkens stærke betoning af rytmen kan rette et spotlight mòd fraværet af en bevidst rytmesøgen i den svenske gymnastik. Fascinationen af rytmesansen var ikke et nyt fænomen, men fandtes f.eks. hos gymnastikpædagogerne Adolf Spiess (tysk) og schweizeren Pestalozzi i begyndelsen af 1800-tallet. Hvorfor dukker dyrkelsen af rytmen op på nogle tidspunkter i gymnastikhistorien for så at forsvinde igen? Rytmen er vel altid til stede i en eller anden forstand, selv i den relativt hårde og kontante »svenske« bevægelseskultur i form af kommando, marchtakt og åndedræt m.v., 
men der er her tale om en langt mindre flydende og bevidst stræben mod tilværelsens rytmiske element. En udgravning af »rytmens historie « kunne sikkert give vigtige impulser til idrætshistorieforskningen, ikke mindst fordi rytmen udvider perspektivet og kildematerialet for den historiske analyse. I denne artikel er synssansen blevet inddraget i form af billedanalyser, en anden indfaldsvinkel kunne altså være at bruge høresansen til en forskning i gamle noder, gymnastikmusik, øvelsernes takt o.s.v.

Heller ikke mandegymnastikken forblev upåvirket af de nye rytmiske og relativt afspændte bevægelsesmønstre, dog i langt mindre omfang end kvindegymnastikken. Springgymnastikken vandt imidlertid mere og mere frem fra midten af 1960 'erne. Hermed var mandegymnastikken blevet integreret i det hastige og dynamiske fremadstræbende bevægelsesmønster, som også prægede så stor en del af det maskuline kropssprog i sport. Indenfor gymnastikken var idealmanden ikke længere kun ham som gennem et nærmest urokkeligt bevægelsesmønster udstrålede mandig fasthed, men i stigende grad ham som udtrykte dynamik og fremadrettethed gennem sine bevægelser. Ifølge Ove Korsgaard er denne tendens imidlertid ikke enerådende, men må levne en vis plads til en ny udvikling i retning af, at især byernes mænd er begyndt at lære af kvindernes integration af musik, rytme og bevægelse! (Ibid., s. 251). Dette må dog ses på baggrund af, at forholdet mellem kvinder og mænd i den frivillige gymnastik i dag er det omvendte af århundredeskiftets gymnastikbevægelse. I dag dominerer kvinderne totalt, så den rytmiske mandegymnastik fylder ikke meget i det kropskulturelle landskab.

\section{Konklusion og perspektivering}

I det foregående er der aftegnet konturerne af en mandighedskult indenfor århundredeskiftets kropskultur. Dyrkelsen af mandigheden ytrede sig kraftigt indenfor så

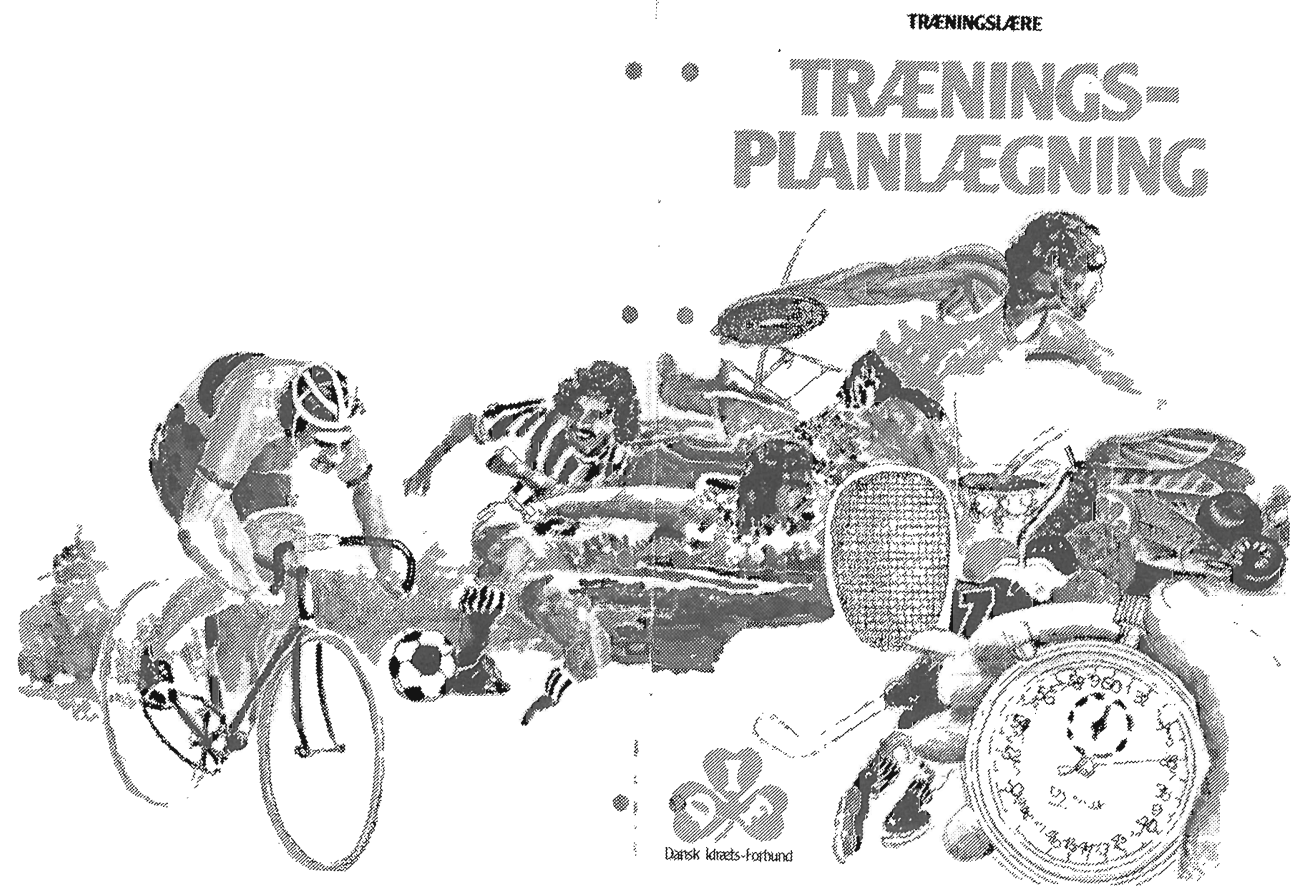

Er sport stadig en mandighedskult? DIF's traningsplanlagning, Kbh. 1981. 
markante bevægelser i det 20'ende århundrede som gymnastik- og sportsbevægelsen (og man kan givetvis tilføje spejderbevægelsen, Kiselberg, 1979).

Mandighedskulten var et bredt socialt fænomen, men den havde en forskellig udformning indenfor forskellige klassekulturer. Borgerskabets sportsmænd var først og fremmest fascinerede af tidssportsgrene, hvor dyrkelsen af hastigheden og fremdriften var central. I arbejdermændenes kraftsportskultur hyldedes »den stærke mand «. Fodboldspillets indtog $\mathrm{i}$ arbejderkulturen markerede dog $\mathrm{i}$ begyndelsen af vort århundrede dyrkelsen af en dynamisk fremad- og (i bogstaveligste forstand) målrettet form for mandighed. Sluttelig tog de grundtvigianske gårdmandssønner i løbet af 1880 'erne en svensk inspireret gymnastikform med et præg af maskulin fasthed, urokkelighed og »rankhed« til deres hjerter.

Forskellen i mandighedsdyrkelsen i den tidlige sport og den svenske gymnastik skal ikke overbetones. I begge bevægelser var der en tendens til at idealisere en mandekrop med en spændt muskulatur, en indtrukken mave, en ranket ryg og en renset hud.

På samme måde blev kropsformningen gennem hærdende øvelser både i sporten og i gymnastikken oplevet som en proces, som ville og skulle påvirke idrætsmandens karakter og moral. F.eks. ville den unge idrætsmand gennem træning kunne opøve sit mod og sin evne til at beherske sig overfor sanselige fristelser.

Århundredeskiftets mandighedsdyrkelse indenfor sport og gymnastik er i det foregående blevet tolket i sammenhæng med periodens voldsomme socialøkonomiske (og politiske) omvæltninger, og med de krav om en stærk selvkontrol som disse omvæltninger medførte for mange mænd.

Det voksende pres på mange mænd ytrede sig f.eks. som stærke krav om at gøre karriere og at administrere tiden mest muligt effektivt (ikke mindst for mange borgerlige mænd). Eller som en kamp for blot at beholde skindet på næsen og ät undgå social og $\varnothing$ konomisk ruin (ikke mindst for store dele af den mandlige arbejderklasse). Eller som en frygt blandt gårdmænd for deklassering og et forsøg på i flok at løfte sig ud af 1880 'ernes landbrugskrise og politiske umyndigg ørelse.

Andre fortolkningsmuligheder overfor århundredeskiftets forsøg på en (gen)rejsning af mandigheden kunne sammenkæde denne rejsning med tesen om en patriarkatskrise i perioden (tak til Bjarne Kildegaard for denne henvisning). En sådan krise kunne f.eks. siges at være rodfæstet i:

a) Kvindernes voksende krav om ligeberettigelse.

b) De socialt højere placerede bykvinders begyndende indtræden på det mandsdominerede arbejdsmarked.

c) Arbejdermændenes sociale »umyndiggørelse« ud fra en traditionel sammenkædning af mandlighed og at have »fod under eget bord « (rådighed over produktionsmidler).

d) Den modercentrerede drengeopdragelse i mange arbejderfamilier, som var stærkt præget af familiefaderens fravær.

e) Erkendelsen (fra 1820'erne) af, at ikke alene sæd-, men også ægcellen var grundlag for livets opståen (Dahlerup, indl.). 
Som en sidste fortolkningsmulighed, som allerede er blevet antydet i det foregående kan nævnes:

f) En angst i mange mænd for at det voldsomt ekspanderende civiliserede byliv (og det mekaniserede landbrugsarbejde?) med dets præg af stillesiddende og ensformigt arbejde ville føre til en underminering af mandens (magt) position i samfundet.

I sportsbevægelsens barndom kan der i hvert fald spores en angst for, at manden i civilisationsprocessens kølvand skulle »degenerere « til et lille, svagt, skaldet, tandløst og ranglet eller fedladent invivid. Opkomsten af de store mandsdominerede, frivillige idrætsbevægelser kan ses som et modtræk overfor undermineringen af en traditionel form for sammenkobling af mandighed og kraftudstråling.

Sportens klart maskuline islæt betød, at kvindernes deltagelse blev begrænset (f.eks. fra fodbold, kraftsport og kaproning) og afgrænset (fra mændenes sportsfællesskab). Det må ses på baggrund heraf, at gymnastikken blev kvindernes foretrukne idræt, en idræt som i sit erklærede æstetiske og sundhedspædagogiske udgangspunkt var mere i pagt med det traditionelle, romantiske kvindeideal.

Den dominerende (»svenske«) gymnastikform omkring århundredeskiftet byggede imidlertid på et militærpræget, maskulint kropssprog, som ikke i længden kunne tilfredsstille gymnastikkvindernes søgen efter at udtrykke deres egen (kulturelt formede) kønsidentitet i gymnastiske bevægelser. Resultatet blev - ikke uden sværdslag - en selvstændig kvindegymnastik med vægt på bevægelighed, rytme, musik-akkompagnement og - især senere i vort århundrede - totale og flydende bevægelser til båndmusik. Denne bevægelseskultur betød et afgørende nybrud i forhold til sportens og den traditionelle mandegymnastiks forherligelse af hårde, rykvise, hurtige og kraftfulde bevægelser.

I takt med at kvinderne gik ind i og forandrede gymnastikken gik mændene mere og mere over til at dyrke sport. De mænd, som standhaftigt fortsatte med at dyrke gymnastik, kan idag siges at have udviklet mandegymnastikken $\mathrm{i} i$ hvert fald to retninger. Den dominerende tendens går i retning af, at mændene nu dyrker en fremadrettet og dynamisk tempofyldt form for springgymnastik, hvorved der er sket en tilnærmelse til især tidssportens bevægelsesmønstre, dog med en bevidst æstetisk stræben som afgørende forskel. En mindre markant tendens går i retning af, at mændene har overtaget elementer fra den rytmiske kvindegymnastik.

Generelt må det siges, at kvinderne igennem det 20'ende århundrede har været relativt ihærdige med at tilegne sig elementer af et moderne »maskulint « kropssprog - ikke mindst ved deres markante indtog i sportsbevægelsen gennem de seneste årtier. Mændene har derimod ikke på tilsvarende vis ønsket, turdet eller følt sig i stand til at tilegne sig et mere »feminint « kropssprog.

Når en kvinde og en mand rækker hænderne i vejret, er der stadig overvejende sandsynlighed for, at det i mandens tilfælde sker for at markere en sejr, et mål, en knockout eller en lignende toppræstation. En kvinde, der gør det samme, kan derimod sagtens tænkes at være i færd med at udføre yndefulde gestikulationer f.eks. som led i en mavedans.

Og dog, er der i dag ikke tale om nogle spæde skridt i retning af en overskridelse af den traditionelle, stålsatte manderolle? Er det ikke et tegn på, at noget er i gære, når 
en fodboldklub i Greve lærer drengene (samba)rytmelære?, når Piontek argumenterer for at skrue præstationspresset ned indenfor drengefodbolden?, når man i enkelte klubber udøver judo til musik?, når (stadig få) mænd begynder at uddanne sig til afspændingspædagoger?, når de gamle rykvise »Kaptajn Jespersen-stræk « mere og mere viger til fordel for lange rolige udspændinger af musklerne?, når drenge stiller sig op på gaden og danser electric boogie for hinanden?, når et kursus i Dansk Idræts-Forbunds regi rummer yoga-nidra-meditation?, når........?

Eller er hovedtendensen blot den, at der desperat søges efter nye veje til at højne præstationsniveauet? Svaret er sikkert både - og.

Afslutningsvis vil jeg sige, at det forekommer mig fattigt, hvis mændene forbliver $\mathrm{i}$ den grøft, hvor alle till $\varnothing \mathrm{b}$ til »feminine«, »sanselige«, og rytmiske bevægelser bliver kvalt i fødslen. For slet ikke at tale om den mulighed, at kvinderne i så høj grad indoptager et »maskulint « kropssprog, at vi ender med en næsten fuldstændig maskuliniseret verden.

Hans Bonde, stud.mag. historie, København.

Hans Bonde studerer historie på Københavns Universitet. Har skrevet

speciale om mandighedsdyrkelsen i den tidlige danske sport.

\section{Litteraturhenvisninger}

Annerstedt, C.: Kvinnoidrottens utveckling i Sverige, Malmö, 1984.

Beyerholm: Dansk Bicycle-Clubs Historie, Kbh., 1941.

Boel, T.: Husmænd og landarbejdere i Danmark, Odense, 1985.

Bonde, H.: En stålsat karakter i et hærdet legeme, speciale, historie, Kbh's Universitet.

Bruhn, C.T.V.: Vejledning i Rideundervisningen, Kbh., 1854.

Centring, Slagelse, 1982/83 (Tidsskrift).

Dahlerup, P.: Det moderne gennembruds kvinder, Kbh. ca. 1984.

Daneved, O.T.: En sund sjæl i et sundt legeme, speciale, Historisk Institut, Århus Universitet, 1978.

Dansk Idroets-Blad: Kbh. 1898-1909.

Dansk socialhistorie: Bd. 5, Kbh. 1982.

Dansk Sportstidende: Kbh. 1883-94.

Eichberg, H.: Leistung, Spannung, Geschwindigkeit, Stuttgart, 1978.

Eichberg, H. og Jespersen, E.: De grønne bølger, Slagelse, 1986.

Elias, N.: Über den Prozess der Zivilisation, I og II Franfurt a.M., 1980 (1930).

Fausing, B. (m.fl.): Billeder af mændenes historie, Kbh. 1984.

Finnemann, N.O.: I broderskabets Aand, Kbh., 1985.

Faye, J.A. og L $\varnothing k k e$, A.: Familieliv i Danmark, Herning, 1986.

Gymnastisk Selskabs Aarsskrift: Kbh., 1904-14. 
Haandbog i Gymnastik: Bd. I og II, Kbh. 1899 (1915).

Hovgaard, W.: Sport, Kbh. 1888.

»Hvorledes vindes et $L \varnothing b$ «, Odense, 1898.

Idraet (tidsskrift), Kbh. 1895-1901.

Idratsbogen, red.: Meyer, A.C., Kbh. 1908 (bd. I) og 09 (bd. II) (forkortes: I.B.).

Illustreret Idratsbog, red.: Hansen, V., Kbh. 1890 (bd. I) og 1893 (bd. II).

Ingemann-Petersen: Cyclesport, Kbh., 1891.

Jørgensen, P., (m.fl.): Idræt og historie, Kbh. 1986.

Kiselberg, S.: To og et halvt kapitel af mændenes historie, Kbh. 1979 (?).

Knudsen, K.A.: Om Sport, Holbæk, 1895.

Knudsen, K.A.: Lærebog i Gymnastik, Kbh., 1930 (1916).

Korsgaard, Ove: Kampen om kroppen, Kbh.. 1982.

Kurz, R. og Prestera, H.: The Body Reveals, New York, 1976.

Lobedanz, A.: Efterskrift til Fressel, Hvad enhver Cyclist bør vide, Kbh., 1895.

Müller, I.P.: Mit system, Kbh., 1904.

Müller, I.P.: Mein System, Leipzig, 1905.

Müller, I.P.: Vink om Sundhedsrøgt og Idræt, Kbh., 1907.

Müller, I.P.: Mit Aandedrætssystem, Kbh. 1915.

Müller, I.P.: Hvad fejler vor Ungdoms fysiske Opdragelse, Kbh., 1927.

Nyegaard, C.A.J.: Om Rideundervisning for Damer, Kbh., 1868.

Orlow Andersen: Hvad enhver Rytterske bør vide, Kbh., 1908.

Reich, W.: Orgasmens funktion, Kbh. 1972 (opr. 1942).

Reiter, A.: Prøv -!, Kbh., 1908.

Sadolin, J.TH., art. i Gymnastisk Selskabs Aarsskrift, 1906, s. 65f.

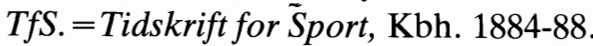

Theilmann: Afsnittet om »Gymnastik « i Idrætsbogen, bd. I, 1908.

Theleweit, K.: Männerphantasien, bd. I, Frankfurt a.M., 1977.

Thörngren, 1912 (05).

Thulin, J.G.: Lärobok i Gymnastik, del III, hæfte 1, Lund, 1924. Og del IV, hæfte 1, (gymnastikatlas) Lund, 1938.

Tidskrift for legemsøvelser, Kbh., 1940/41.

»Traeningsplanlagning «, D.I.F., Kbh., 1981 (pjece).

Varnild, Ib: »Sport som folkelig forlystelse« i: For sportens skyld, Nationalmuseet, Kbh. 1972.

Verdensspejlet, Kbh., 1902/03.

Vigarello: Le corps redressé, Paris, 1978.

Vort Hjem, Kbh., 1903.

Wex, M.: Weibliche und männliche Körpersprache als folge patriarchalischer Machtverhältnisse, ca. 1978. 